This is the final peer-reviewed accepted manuscript of:

De Waele, Jo; Picotti, Vincenzo; Martina, Mario L. V.; Brook, George; Yang, Linhai; Forti, Paolo: Holocene evolution of halite caves in the Cordillera de la Sal (Central Atacama, Chile) in different climate conditions. Geomorphology 370. 1-14. DOI: 10.1016/j.geomorph.2020.107398

The final published version is available online at: http://dx.doi.org/10.1016/i.geomorph.2020.107398

Rights / License:

The terms and conditions for the reuse of this version of the manuscript are specified in the publishing policy. For all terms of use and more information see the publisher's website. 


\title{
Holocene evolution of halite caves in the Cordillera de la Sal (Central Atacama, Chile) in different climate conditions
}

\author{
Jo De Waele ${ }^{a, f} f_{, *}$, Vincenzo Picotti ${ }^{a, b}$, Mario L.V. Martina ${ }^{c}$, George Brook ${ }^{d}$, Linhai Yang ${ }^{d, e}$, Paolo Forti ${ }^{a, f}$ \\ a Dipartimento di Scienze Biologiche, Geologiche e Ambientali, Università di Bologna, Via Zamboni 67, 40126 Bologna, Italy \\ ${ }^{\mathrm{b}}$ ETH, Institute of Geology, Department of Earth Sciences, Soneggstrasse 5, 8092 Zürich, Switzerland \\ c Scuola Universitaria Superiore IUSS Pavia, Palazzo del Broletto, Piazza Vittoria 15, 27100 Pavia, Italy \\ ${ }^{\mathrm{d}}$ Department of Geography, University of Georgia, Athens, GA 30602, USA \\ ${ }^{\mathrm{e}}$ Key Laboratory of Desert and Desertification, Cold and Arid Regions Environmental and Engineering Research Institute, Chinese Academy of Sciences, No. 320, West Donggang Road, Lanzhou, \\ Gansu Province 730000, PR China \\ ${ }^{\mathrm{f}}$ La Venta Esplorazioni Geografiche Association, Via Priamo Tron 35/F, 31100 Treviso, Italy
}

\section{A R T ICLE INFO}

\section{Article history:}

Received 29 May 2020

Received in revised form 23 August 2020

Accepted 23 August 2020

Available online $\mathrm{xxx}$

\section{Keywords}

Geomorphology

Paleoclimate

Halite caves

Floods

OSL dating

Radiocarbon dating

\begin{abstract}
A B S T R A C T
Geomorphological studies have been carried out in rapidly evolving salt caves related to small watersheds in the San Pedro de Atacama area, Chile. Radiocarbon ages of bones and wood from cave deposits, combined with the presence of large salt caves, geomorphological and sedimentological observations, and the results of micrometer measurements outside and in some of the caves, suggest a period of speleogenesis in the Cordillera de la Sal during the onset of the Holocene, during which the large halite cave systems developed, followed by an early Holocene hyperarid period. Most smaller caves (i.e. Lechuza del Campanario) most probably formed at the start of the wetter mid-Holocene period (5-4.4 ka), when precipitation was never intense enough to entrain large amounts of sediments, but enough to trigger cave development. A diamicton in Lechuza del Campanario Cave radiocarbon dated at ca. 4.4 ka shows that at least one high intensity rainfall event occurred in this recharge basin during the mid-Holocene wet interval. A wet period with lower intensity rainfall events followed between 4.0 and $2.5 \mathrm{ka}$, causing the $4.4 \mathrm{kyrs}$ old diamicton in Lechuza del Campanario Cave to be entrenched, and the alluvial fan at the downstream end of Palacio del Sal Cave to be covered with windborne sediments dated by OSL at around $3.6 \mathrm{ka}$. At ca. 2 ka there was a high-intensity rainfall event documented by the age of a twig stuck in the ceiling of the Palacio del Sal Cave, followed by a period with lower intensity rain events until ca. $1.3 \mathrm{ka}$, when another intense flood produced a mudflow that deposited a second diamicton in Lechuza del Campanario Cave. From then on clustering of radiocarbon ages for wood and bone recovered from caves indicates increased rainfall intensity in the period ca. 0.9-0.5 ka, followed by no registered events until a minor flood at ca. $0.13 \mathrm{ka}$. The four-centuries long wetter time interval (0.9-0.5 ka), corresponding to the Medieval Climate Anomaly, has been an archaeologically important period in the Atacama Desert (Tiwanaku culture).The observations and a detailed review of paleoclimate literature from this key area have allowed the development of a landscape evolution model related to changing climate conditions during the Late Holocene.
\end{abstract}

(C) 2020

\section{Introduction}

The Atacama Desert, and especially the area around the Salar de Atacama $\left(23^{\circ} \mathrm{S}, 68^{\circ} 10^{\prime} \mathrm{W}\right.$, ca. $2500 \mathrm{~m}$ asl, Chile) is among the driest places on Earth, with mean annual rainfall below $25 \mathrm{~mm}$ (Houston and Hartley, 2003; De Waele and Forti, 2010). Rainfall increases with elevation but is below $200 \mathrm{~mm} / \mathrm{yr}$ over the entire region (Houston, 2006). The marked aridity started well before the onset of the Quaternary (Hartley and Chong, 2002; Dunai et al., 2005; Garreaud et al., 2010; Rech et al., 2006,

\footnotetext{
* Corresponding author at: Dipartimento di Scienze Biologiche, Geologiche e Ambientali, Università di Bologna, Via Zamboni 67, 40126 Bologna, Italy.

E-mail addresses: jo.dewaele@unibo.it (J. De Waele); vincenzo.picotti@erdw.ethz.ch (V. Picotti); mario.martina@iusspavia.it (M.L.V. Martina); gabrook@uga.edu (G. Brook);
} ylh@lzb.ac.cn (L. Yang); paolo.forti@unibo.it (P. Forti)
2010). Certainly, this aridity was interrupted by wetter periods (Placzek et al., 2010), mostly during cooler intervals of the Quaternary for the Altiplano (Jungers et al., 2013), but hyperaridity appears to have been dominant during the last $3 \mathrm{Myr}$ (Hartley and Chong, 2002). Three factors are considered responsible for the arid climate (Houston, 2006; Garreaud et al., 2009): 1) the latitude, where permanent subtropical highs prevail such as the SE-Pacific anticyclone; 2) the presence of the Rutland cell in the western Pacific, which brings cold water close to the coast (Humboldt Current) creating a temperature inversion that inhibits the transport of Pacific moisture eastward over the continent, and 3) the rain shadow effect of the Andes mountain chains. The combination of these three conditions has persisted over the last 30 Myr (Dunai et al., 2005; Horton, 2018), establishing the semi-arid to hyperarid climate we still observe today.

Most of today's rain in the Salar de Atacama occurs during summer and comes from Amazonian areas, whereas winter rains from the Pacific Ocean are very rare. The 20-year average precipitation field provided 
et al. (2003), is below $2 \mathrm{~mm} \mathrm{~d}^{-1}$ (for single rain events). Both summer and winter rainfall are greatly influenced by ENSO, with an accentuation of hyper-aridity and decreasing input of Atlantic moisture during El Niño years, characterized by weakened trade winds (Houston, 2006), and increasing summer rains during La Niña years driven by strengthened trade winds (Betancourt et al., 2000; Garreaud and Aceituno, 2001; Garreaud et al., 2003; Magilligan et al., 2008; Quade et al., 2008). Rainfall records for the last centuries indicate that the most extreme rain events are in El Niño years, while La Niña brings increased annual precipitation but not extreme floods, except in the mainstem valleys (Ortlieb, 1994; Morales et al., 2012).

The study of a $106 \mathrm{kyr}$ old salt core from the center of the Salar de Atacama, although biased by quite large experimental uncertainties in the U/Th dates, documents several wet periods at 75.7-60.7, 53.4-15.5, 11.4-10.2 and 6.2-3.5 ka, with the wettest period being from $26.7 \mathrm{ka}$ to $16.6 \mathrm{ka}$ (Bobst et al., 2001) (Fig. 1). In a study of paleo-wetlands in Salar de Punta Negra approximately $150 \mathrm{~km} \mathrm{~S}$ of Salar de Atacama ( $25^{\circ} \mathrm{S}$ ), Quade et al. (2008) found evidence for two distinct wetter periods from $15.9-13.8 \mathrm{ka}$ and $12.7-9.7 \mathrm{ka}$. In the Sierra de Varas immediately $\mathrm{S}$ of Salar de Punta Negra, groundwater discharge deposits point to three wet periods at around $14.5 \mathrm{ka}$, between 12.2 and $9.8 \mathrm{ka}$, and in the last $4.7 \mathrm{ka}$ (Saez et al., 2016). Studies of lake sediments and paleolake levels in the Altiplano indicate wetter conditions between 14.0 and $9.5 \mathrm{ka}$ with conditions shifting rapidly to hyperarid (more arid than today) between 9.0 and 4.0 ka except for a more humid century-scale period between 6.0 and 5.5 ka (Grosjean et al., 2001, 2003). Onset of a hyperarid climate in the central Atacama Desert is supported by evidence of a decrease in human occupation between 9.0 and 6.7 ka (Grosjean et al., 2007).

Paleoclimate records from middle-elevation (2500-3200 m asl) rodent middens show a wetter phase between 16.2 and 10.5 ka peaking at $11.8-10.5 \mathrm{ka}$, followed by an extremely arid phase until $7.1 \mathrm{ka}$ that was followed by a wetter phase until $3.5 \mathrm{ka}$. The onset of the present hyperarid climate is set at $3 \mathrm{ka}$ (Latorre et al., 2002). Rodent middens at higher elevations in the same area record wetter phases at 13.5-9.6, 7.6-6.3, 4.4-3.2 and possibly 1.8-1.2 ka, and dry phases at 9.4-8.4 and possibly around $5.1 \mathrm{ka}$ (Latorre et al., 2003). Middens at lower elevations (ca. 2900-3150 m asl) along the Rio Salado have provided evidence of wetter periods around 17.5-16.3 (very wet), $11.8-9.6, \quad 7.3-6.7, \quad 3.5-2.3$ and at $0.8 \mathrm{ka}$, while ex-

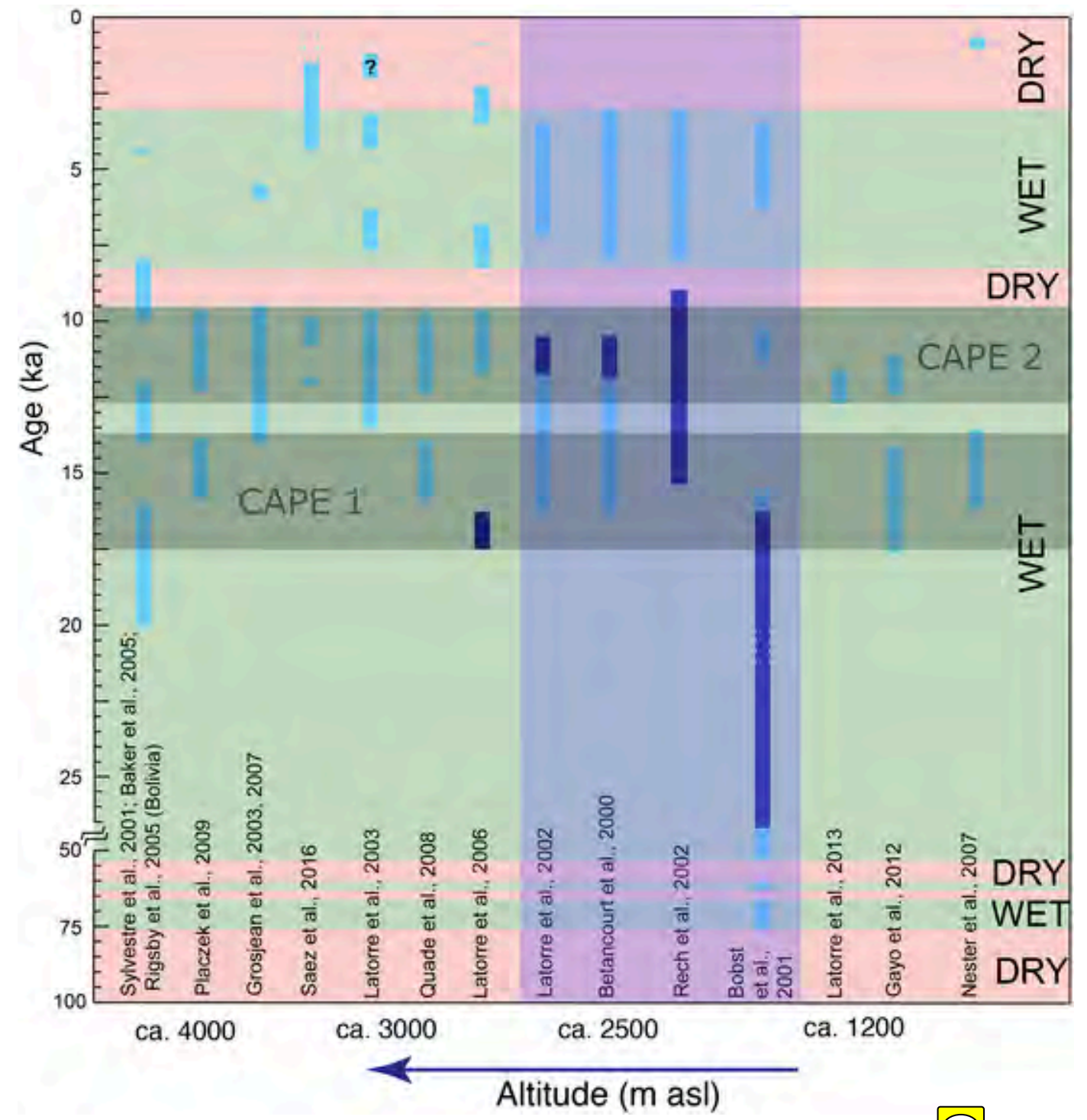

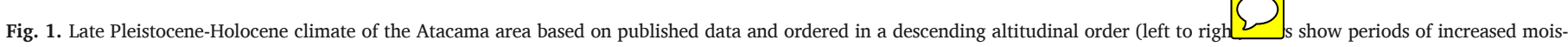

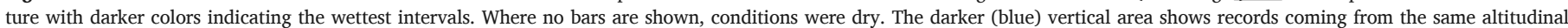

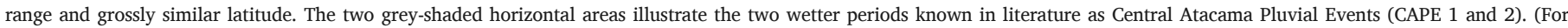
interpretation of the references to color in this figure legend, the reader is referred to the web version of this article.) 
treme arid periods are indicated at 14.2, 8.9-8.6 and 4.9 ka (Latorre et al., 2006). The Late Glacial and very early Holocene period of increased rainfall has been termed the Central Atacama Pluvial Event (CAPE) (Latorre et al., 2006), later redefined by some authors as the Central Andean Pluvial Event, that lasted from ca. 17.6 ka to 9.7 ka (Quade et al., 2008; Placzek et al., 2009). This pluvial period was characterized by two wet intervals at 17.6-13.8 ka (CAPE 1) and 12.7-9.7 ka (CAPE 2), separated by a short period of hyperaridity (Latorre et al., 2013).

It is clear from the evidence presented abo reconstructions of past climate are proxy- and location- depende this framework, an increasing number of local studies using different paleoclimate proxies in the Atacama area will contribute to forming a more general framework on how climate changed in the recent past at different altitudinal and geographic locations. In this study, we present geomorphic evidence from salt caves in the Cordillera de la Sal of variations in stream discharge in small watersheds, and thus rainfall events, during the Late Pleistocene and Holocene. The salt caves in this area - one of the few locations in the world with caves developed in halite (Frumkin et al., 1991: Frumkin, 1998; Bosák et al., 1999; Bruthans et al., 2010) are unique archives of paleo-environmental and paleoclimatic changes. We explored the effects of different climate regimes on landscape evolution, as recorded by the salt cave systems of the Cordillera de la Sal during the Holocene.

\section{Study area}

\subsection{Location}

The study area is in the northern part of the Salar de Atacama, near the village of San Pedro, Chile: it is an intra-montane basin located between the volcanic ridge that forms the backbone of the Andes (Western Cordillera) and the mountain range Cordillera Domeyko to the W (Fig. 2). The Cordillera de la Sal is a NW-SE elongated fold- and thrust-belt several $\mathrm{km}$ wide and over $100 \mathrm{~km}$ long. The region immediately $\mathrm{N}$ and $\mathrm{S}$ of the village is dotted with canyons and cave entrances that sometimes bear important archeological sites.

There have been several cave expeditions to the Cordillera de la Sal beginning in the early 1990s (Salomon, 1995). These have led to the discovery of about 50 caves totaling over $20 \mathrm{~km}$ in length (Fryer, 2005; Sesiano, 2006, 2009; Padovan, 2015; De Waele and Padovan, 2016; De Waele et al., 2019). The caves located far from roads and human settlements (over $20 \mathrm{~km}$ ) are hard to reach, and although being the longest (several $\mathrm{km}$ long) and deepest ( $230 \mathrm{~m}$ deep) and most beautiful ones, they are devoid of organic remains (vegetal and animal) being hosted in an area with no vegetation at all. These caves have delivered a rich association of cave minerals (over 15) and a great variety of speleothems (De Waele et al., 2017). The caves closer to the San Pedro de Atacama village are easier to reach, host archeological remains, and have some sparse vegetation growing and free-wandering animals feeding in their recharge areas. Most caves are closely related to small drainage basins, with valleys flowing at the surface and disappearing when they encounter the outcropping, often steeply dipping halite rocks.

\subsection{Geology}

The oldest rocks of the Cordillera de la Sal are Oligocene-Miocene continental sediments of the Paciencia Group, which includes $20-60 \mathrm{~m}$ thick interbedded rock salt units. In the subsurface, thicker intervals of this unit occur, complicated by the presence of halokinesis (e.g. Rubilar et al., 2017). These deposits cover an even thicker sedimentary sequence of Cretaceous-Eocene age known as the Purilactis Group, which crop out in the Cordillera de Domeyko that bounds the Salar to the west. The Paciencia Group is unconformably overlain by the Vilama Group, a succession of Miocene to Pleistocene volcanics, ignimbrites and continental, mostly alluvial, sediments (Evenstar et al., 2015).
To the north of the Cordillera de la Sal, the rhyolitic ignimbrite and associated pyroclastic deposits of the Artola Ignimbrite, the base of the Vilama Group (Evenstar et al., 2015), unconformably overlie the previous succession. The ignimbritic succession thins to the south and west, grading into pyroclastic deposits: it documents the first products of the new volcanic arc located to the east. We sampled and dated by $\mathrm{U} / \mathrm{Pb}$ SHRIMP the zircons of the Artola Ignimbrite at $9.20 \pm 0.11 \mathrm{Ma}$ (Bert De Waele, personal communication). This age confirms the published $\mathrm{K}-$ Ar age of $9.5 \pm 0.3 \mathrm{Ma}$ for the Artola Ignimbrite, reviewed in Muñoz et al. (2002) and Evenstar et al. (2015). The Late Miocene to Pliocene succession of ignimbrites, pyroclastic and alluvial deposits again shows thinning over the top of the Cordillera de la Sal, which is deformed as a broader anticline. At the eastern mountain front towards the Salar, the Vilama Group is steeply dipping and less than $40 \mathrm{~m}$ thick, and it shows a clear divergent pattern, passing upsection into the gently dipping surficial gravels of the border pediment. These last units reach more than one thousand meters in the Salar subsurface immediately east of the thrust (Jordan et al., 2007; Rubilar et al., 2017), documenting the clear control of tectonic subsidence.

\section{Material and methods}

\subsection{Caves and karst of the Cordillera de la Sal}

Some caves southwest of San Pedro Village, north of the Valle de la Luna, a tourist area, have been studied in detail because of their accessibility, reasonable length and the presence of interesting features (e.g. speleothems, sediment deposits, morphology). The most important of these is the 600-m long Cueva Lechuza del Campanario (Barn Owl Cave), mapped by a compass and tape survey and, in 2015 and 2018, with a laser scanner. Bones and twigs brought into the caves by flood events in Cueva Lechuza del Campanario and also in the Palacio del Sal, Chulacao, and fossil Chulacao (an alcove formed by an abandoned fragment of halite cave, now $15 \mathrm{~m}$ above the present cave river bed) caves were photographed, their locations noted, and cemented samples were extracted using a hammer. Twigs stuck in fissures in the ceilings or walls of caves were removed by hand and their height above the present cave floor was measured.

Halite dissolution rates were measured using 7 Micro Erosion Meter stations (MEM-stations) (High and Hanna, 1970; Trudgill et al., 1981) placed on bare rock salt surfaces and set up in November 2007. These stations are composed of 5 stainless steel nails allowing for the measurement of 3 spots/station. Two of these stations have been placed on exposed horizontal rock salt surfaces (Chulacao and Valle de la Luna), two on vertical bare rock salt walls (same locations), two respectively on the roof and on a lateral horizontal bench $2 \mathrm{~m}$ above the floor in Lechuza de Campanario (Barn Owl) cave and the remaining on a salt block along the canyon floor of Quebrada Lechuza. Measurements were carried out in November 2007, immediately and a couple of days after the station emplacement, in the period March-April of 2008, November 2011, November 2015 and in March 2018 (only two of the cave stations).

\subsection{Radiocarbon dating}

In the laboratory, wood samples were treated with $5 \% \mathrm{HCl}$ at $80{ }^{\circ} \mathrm{C}$ for $1 \mathrm{~h}$ then washed with deionized water on a fiberglass filter and rinsed with diluted $\mathrm{NaOH}$ to remove possible contamination by humic acids. The sample was then treated with dilute $\mathrm{HCl}$ again, washed with deionized water and dried at $60{ }^{\circ} \mathrm{C}$.

Bone samples were dated using the collagen fraction. The bone was cleaned using a wire brush and washed in an ultrasonic bath. After cleaning, the dried bone was gently crushed to small fragments. The physically-cleaned sample was reacted with $1 \mathrm{~N} \mathrm{HCl}$ for $24 \mathrm{~h}$ at $4{ }^{\circ} \mathrm{C}$ to dissolve the bone minerals. The residue was filtered, rinsed with $0.1 \mathrm{~N} \mathrm{NaOH}$ to remove possible contamination by humid acids, then rinsed with $1 \mathrm{~N} \mathrm{HCl}$ to remove any alkali residue and finally rinsed with deionized water and under acid conditions $(\mathrm{pH}=3)$ heated at $80{ }^{\circ} \mathrm{C}$ for $6 \mathrm{~h}$ to dissolve collagen. The colla- 

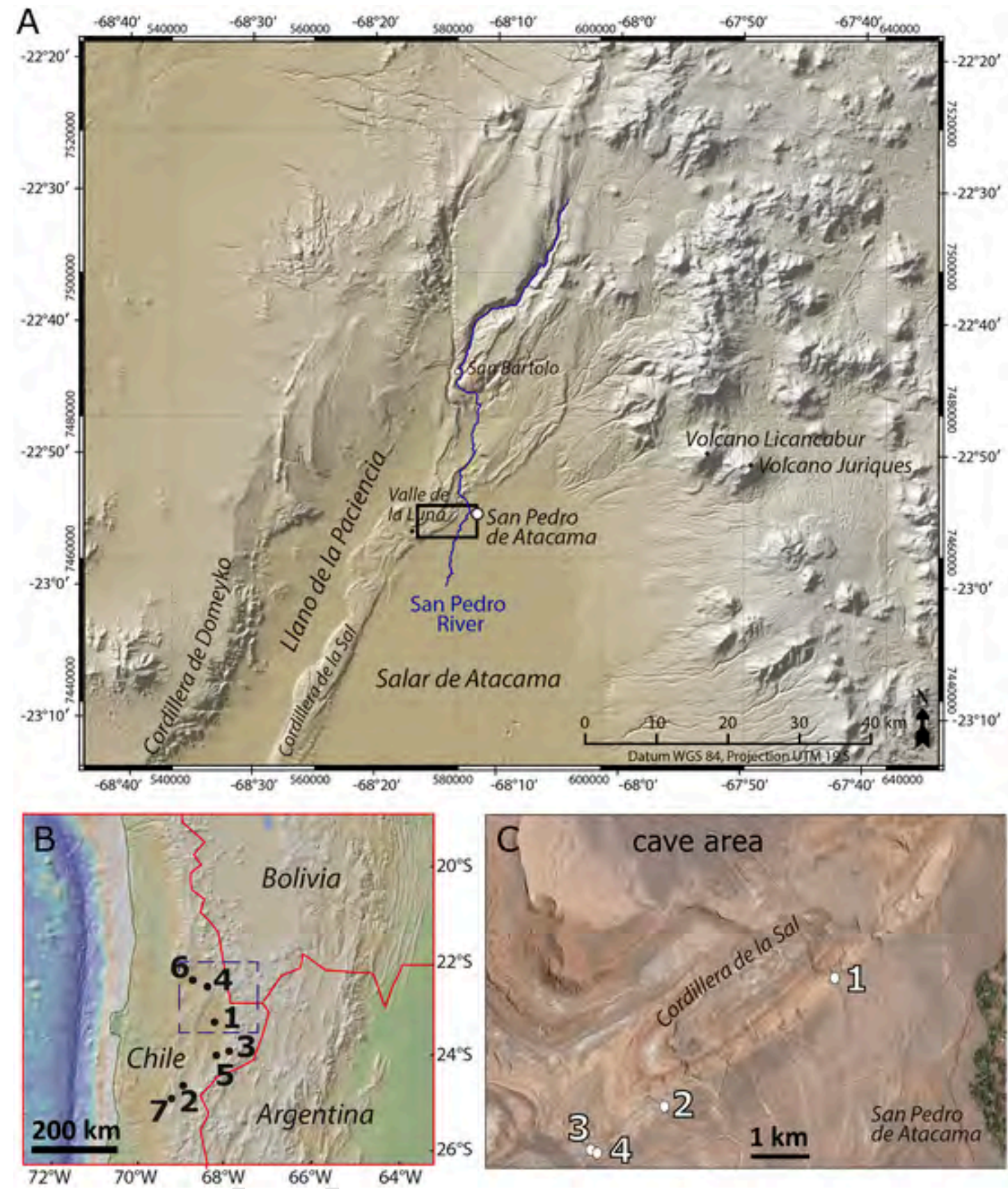

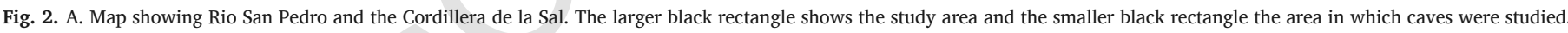

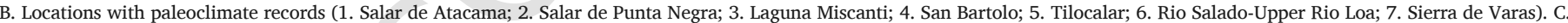
Caves investigated in the Cordillera de la Sal: 1. Chulacao; 2. Lechuza del Campanario; 3. Palacio del Sal; 4. Paisaje del Sal.

gen solution was then filtered to isolate pure collagen and dried. The dried collagen was combusted at $575{ }^{\circ} \mathrm{C}$ in evacuated/sealed Pyrex ampoules in the presence of $\mathrm{CuO}$.

For accelerator mass spectrometry analysis, the cleaned samples were combusted at $900{ }^{\circ} \mathrm{C}$ in evacuated/sealed ampoules in the presence of $\mathrm{CuO}$. The resulting carbon dioxide was cryogenically purified from the other reaction products and catalytically converted to graphite using the method of Vogel et al. (1984). Graphite ${ }^{14} \mathrm{C} /{ }^{13} \mathrm{C}$ ratios were measured using the CAIS $0.5 \mathrm{MeV}$ accelerator mass spectrometer at the Center for Applied Isotope Studies, University of Georgia. The sample ratios were compared to the ratio measured from the Oxalic Acid I (NBS SRM 4990). Sample ${ }^{13} \mathrm{C} /{ }^{12} \mathrm{C}$ ratios were measured separately using a stable isotope ratio mass spectrome- ter and expressed as $\delta^{13} \mathrm{C}$ with respect to PDB, with an error of less than $0.1 \%$.

The quoted uncalibrated dates are in radiocarbon years before 1950 $\left({ }^{14} \mathrm{C}\right.$ yr BP), using the ${ }^{14} \mathrm{C}$ half-life of 5568 years. The error is quoted as one standard deviation and reflects both statistical and experimental errors. Dates have been corrected for isotopic fractionation assuming that the samples originally had a $\delta^{13} \mathrm{C}$ of $-25 \%$. Radiocarbon ages were calibrated at the $2 \sigma$ probability level to give calendar years BP (cal yr B.P.) using CALIB 7.1 (Stuiver and Reimer, 1993) and the Southern Hemisphere (SHcal13) atmospheric calibration curve of Hogg et al. (2013). 


\subsection{OSL dating techniques}

One sand sample has been taken with a 5-cm diameter plastic tube at the exit of Palacio del Sal Cave, on top of an alluvial fan deposit coming out of the cave, and has been dated with OSL. Sample preparation and OSL measurements were carried out in the University of Georgia Luminescence Dating Laboratory. The sample was opened in the laboratory under subdued red light conditions. The top and bottom $5 \mathrm{~cm}$ of the sediment in the pipe were removed. The potentially light-exposed sediment was stored in plastic bags to be used later for sample annual dose rate estimation. The raw sample was treated with $10 \% \mathrm{HCl}$ and $20 \% \mathrm{H}_{2} \mathrm{O}_{2}$ to remove carbonate and organic matter. After drying, the sample was sieved to obtain grains in the $150-180 \mu \mathrm{m}$ size range. Heavy liquids with densities of 2.62 and $2.75 \mathrm{~g} / \mathrm{cm}^{3}$ were then used to separate the quartz grains in this size fraction. The resulting quartz grains were treated with $40 \% \mathrm{HF}$ for $60 \mathrm{~min}$ to remove the outer layer irradiated by alpha particles and any remaining feldspar grains. They were then treated with $10 \% \mathrm{HCl}$ for $10 \mathrm{~min}$ to remove fluorides created during the HF etching. The purity of quartz was checked by IRSL at $50{ }^{\circ} \mathrm{C}$ and the results showed that none of the samples contained feldspar in the quartz fraction. The purified quartz grains were then mounted on the center part of stainless steel disks (with a diameter of $1 \mathrm{~cm}$ ) using silicone oil for OSL measurements.

OSL measurements were carried out using an automated Risø TL/ OSL-DA-15 Reader (Markey et al., 1997). Light stimulation of quartz mineral extracts was undertaken with an excitation unit containing blue light-emitting diodes $(\lambda=470 \pm 30 \mathrm{~nm}$ ) (Bøtter-Jensen et al., 1999). Detection optics comprised two Hoya $2.5 \mathrm{~mm}$ thick U340 filters and a $3 \mathrm{~mm}$ thick stimulation Schott GG420 filter coupled to an EMI 9635 QA photomultiplier tube. Laboratory irradiation was carried out using a calibrated $90 \mathrm{Sr} / 90 \mathrm{Y}$ source mounted within the Reader.

The equivalent dose $\left(D_{e}\right)$ was measured using a routine single aliquot regenerative-dose (SAR) protocol (Murray and Wintle, 2000). A preheat-plateau dose-recovery (PP-DR) test was performed on the sample at six preheat temperature points $\left(180-280^{\circ} \mathrm{C}\right.$ with an interval of $20^{\circ} \mathrm{C}$ and a cut-heat of $160{ }^{\circ} \mathrm{C}$ ) to determine the most appropriate preheat temperature for the sample and to check if a given dose could be recovered by the SAR protocol. A good PP-DR plateau was obtained in the temperature range $180-280{ }^{\circ} \mathrm{C}$ and because of this we used a preheat temperature of $200{ }^{\circ} \mathrm{C}$ and a cut-heat of $160{ }^{\circ} \mathrm{C}$ in our quartz OSL SAR protocol.

For $\mathrm{D}_{\mathrm{e}}$ determination, dose-response curves were constructed using three regenerative dose points, a zero-dose point and a repeat point. The initial OSL signals integrated over $0.80 \mathrm{~s}$ (1-5 channels) were subtracted by 'early background' (6-30 channels) to avoid a contribution of medium and slow components (Cunningham and Wallinga, 2010). Among the 24 measured aliquots, any that exceeded the acceptable range for the recycling ratio (0.9-1.1) and recuperation (10\%) were excluded from the $\mathrm{D}_{\mathrm{e}}$ calculation. Data were analyzed using the ANALYST program of Duller (1999).

Dose rate is created by the radioactive elements existing in grains of the sample and the surrounding sediments, with a small contribution from cosmic rays. For all the samples measured, a thick source Daybreak alpha counting system was used to estimate $U$ and Th for dose rate calculations. K contents were measured at the SGS Laboratory in Canada by ICP90, using the sodium peroxide fusion technique. All measurements were converted to alpha, beta and gamma dose rates according to the conversion factors of Aitken $(1985,1998)$. The effect of water content and additional contributions from cosmic-rays were also taken into account. The water content was estimated at $5 \pm 2.5 \%$ for all samples. The cosmic-ray contribution to the dose rate was calculated from the burial depth, longitude, latitude and elevation of the sample location following Prescott and Hutton (1994).

In dating fluvial and aeolian deposits, it is always possible that some sand grains were incompletely bleached before deposition or were incorporated into the sediment by post-depositional mixing, or a combination of these. Even in deposits containing sands that were fully bleached

deposi- tion, it is possible that these were mixed subsequently with younger, intrusive grains (Galbraith and Roberts, 2012). Whether the samples were fully bleached prior to burial can be detected by examining the distribution or overdispersion (OD) among $\mathrm{D}_{\mathrm{e}}$ values obtained from many individual aliquots from the same sample. OD is the amount of scatter left after all sources of measurement uncertainty are taken into account. The OD value for our sample was $27 \%$ which may indicate partial bleaching of these deposits, or the addition of younger sand grains after the initial burial of the sediment. Because a minimum age model $\left(\mathrm{MAM}^{1}\right)$ can be more appropriate for partially bleached samples, and a maximum age model $\left(\mathrm{MAM}^{2}\right)$ for sediments infiltrated by younger sand grains, we have estimated minimum and maximum ages as well as central (CAM) ages (Galbraith et al., 1999) for the deposit we dated as a possible aid in interpreting the environmental history of our study area.

\section{Results}

\subsection{Salt dissolution and cave morphology}

All of the salt caves studied are "through caves", in that they can be followed from entrance to exit. Their catchments are usually extended mostly over insoluble material, gypsiferous marls, and fine aeolian sands. The cave entrances in salt are usually vertical (salt shafts or collapses) and rapidly reach a sub-horizontal passage that slopes gently towards the exit. Cave passages are formed in vadose conditions, by temporarily flowing waters, and phreatic conduit passages are extremely rare and caused by local factors (i.e. collapses). The slopes of trunk passages are around 3\%o (sub-horizontal) if measured along the cave floors. An interesting feature in some of the caves is the presence of short (up to 2 -m high) vertical drops (knickpoints) along the underground riverbed. These abrupt steps are associated with fault planes and, most probably, are related to active tectonic movements of the Cordillera de la Sal ridge. The downstream entrance of Cueva Lechuza del Campanario is a 4-m-high halite flowstone step giving access to the almost horizontal meandering passage above.

Cave river passages are surprisingly "clean", with very little to no breakdown or recent mass wasting deposits. It appears that dissolution by occasional flood-generated streamlets is able to remove all material quick enough, and that rockfall is generally rare and of small volumes. In small-to-medium sized caves with narrow entrances the cave floor is covered with salt crusts and very thin alluvial sediments (marls and fine sands), and often the halite bedrock is outcropping. Our observations during 4 visits to Lechuza del Campanario Cave spanning almost 10 years show some downcutting and sediment entrainment to have occurred during the documented floods. This cave, with its rather small drainage basin, still appears to be in an intermediate stage of development, with downcutting still taking place but seemingly unable to keep pace with the uplift rate of the bedrock. Larger caves such as Chulacao or Palacio del Sal have floors covered with fine grained alluvial and aeolian sediments. During important flood episodes these sediments are easily entrained by running waters, resulting in an almost perfectly flat floor.

One of the most striking features of the salt caves is the development of vadose canyons with laterally eroding meanders (Fig. 3). Observations in different caves show these meanders are generally not related to bedrock features (e.g., fractures) and have a different sinuosity at different elevations along the cave passage.

Passage cross-sections change shape vertically following meander entrenchment, but passage width remains more or less constant. In some upper (older) levels the width of the channel is greater. These wider upper cave passages also show a wider meander curvature compared with the narrower lower parts of the passages, where meander curvature may sometimes be extremely small. Similar data were also obtained in limestone caves by Deike and White (1969). The floors of the meandering passages are covered with a white salt crust suggesting that water still flows along them occasionally (Fig. 3A-C). Generally, the salt crust covers a thin (some $\mathrm{dm}$ ) layer of clayey material, fine sands, or immediately cover the halite bedrock. 

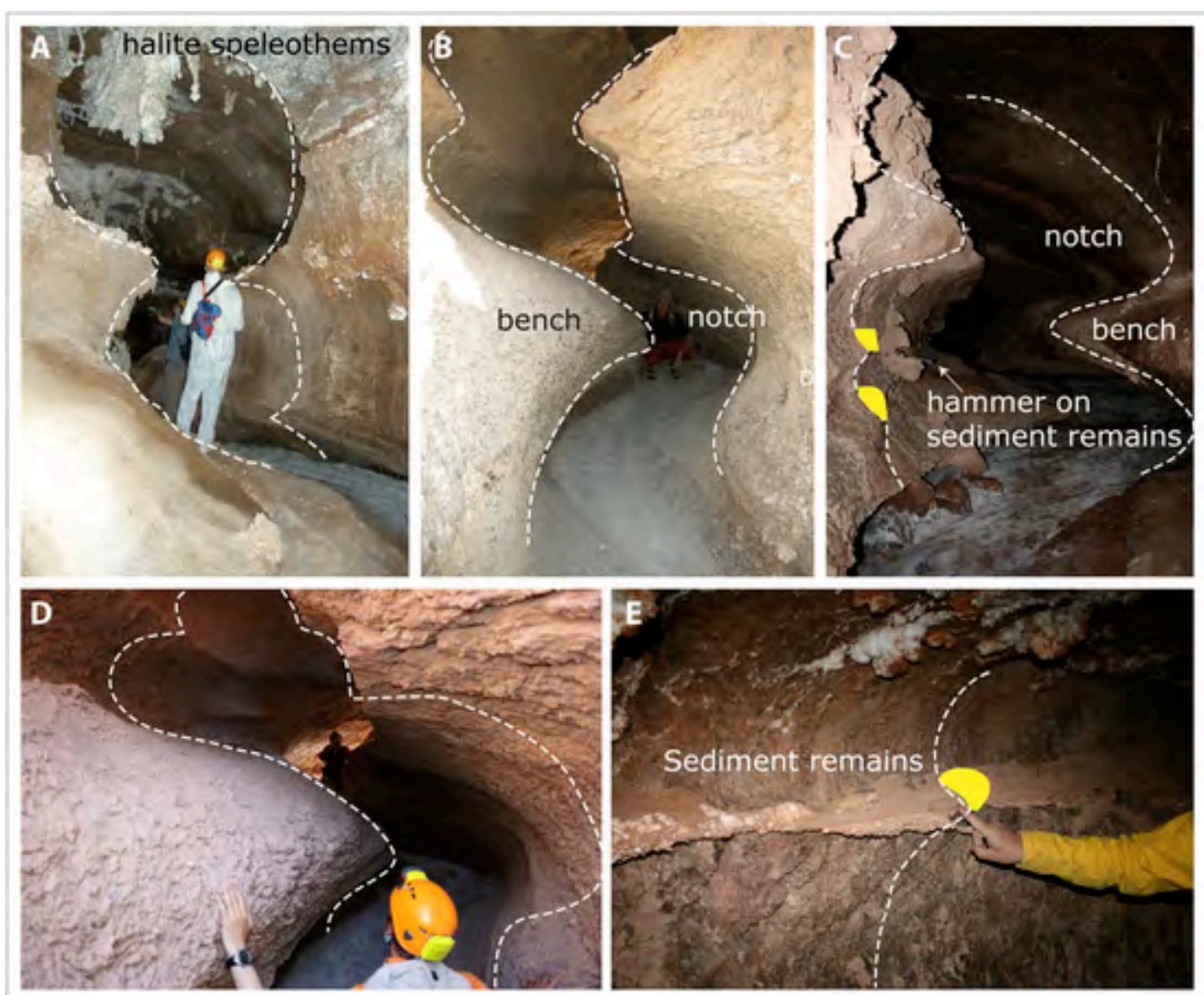

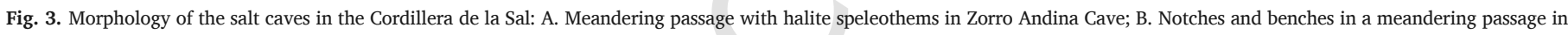

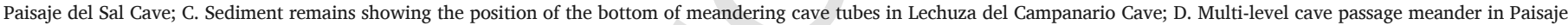
del Sal Cave; E. Sediment floor showing the position of an old cave river thalweg in Lechuza del Campanario.

Some cave passages are partially filled with diamictons that are evidence of past hyper-concentrated sediment flows into the caves (Fig. 3C and E). The high solid/fluid ratio was such that some debris flows stopped flowing after entering the cave, filling it locally. This is very different from the typical situation in more temperate climate settings, where less dense flows are normally flushed through the entire cave (Van Gundy and White, 2009). These diamictons were supplied by the mud-rich bedrock upstream the caves. The most interesting diamictons are those in Lechuza del Campanario Cave, where the reduced dimensions of the meandering cave passage allowed their preservation in recessed parts of the passage. They are laid down on what was the rock salt bottom of the cave passage, and were later entrenched by successive downcutting streams (Fig. 3C and E). In this cave, these deposits contain bones and twigs that have allowed estimation of the maximum age of these debris flows (Fig. 6).

At the Cueva Palacio del Sal, we observed sand deposits forming small terraces in the lower channel reach. This well-sorted sand shows convolutions due to water escape during settling, a feature typical of the freezing grain flows. These non-cohesive sediments were more efficiently transported through the entire length of the caves and were eventually deposited at the outlet, forming an alluvial fan downstream the cave. The top sediments of the fan, downstream of Cueva Palacio del Sal, provided an OSL CAM age of $3.6 \pm 0.3 \mathrm{ka}$, and minimum and maximum ages of $2.3 \pm 0.2 \mathrm{ka}$ and $8.3 \pm 0.8$ ka respectively (Table 1$)$.

Of the 7 MEM stations, only two survived over the ten-year period (the two in-cave stations) (Table 2). One station placed in the Quebrada Lechuza was dissolved during a rain event that occurred between November 2007 and April 2008 (Fig. 5A-B). This activation of the small creek that carved Lechuza del Campanario cave, likely in the form of a flash flood, was able to dissolve the salt block lying in the river bed for at least $2 \mathrm{~cm}$. All other external stations were found completely dissolved in November 2015, eight years after their emplacement, and taking into account the micro-erosion meter measurements only, have shown lowering rates ranging between 0.4 and $1.73 \mathrm{~mm} /$ $\mathrm{yr}$ on vertical walls and a mean value of $0.80 \mathrm{~mm} / \mathrm{yr}$ on horizontal salt surfaces. The two MEM stations in the cave, placed well above

Table 1

OSL results and age data for the aeolian sands at the exit of Palacio del Sal Cave, UGA Lab ID 660, sample ID P09-615, number of aliquots analyzed = 18.

\begin{tabular}{|c|c|c|c|c|c|c|c|c|c|c|c|}
\hline $\begin{array}{l}\text { U } \\
\text { (ppm) }\end{array}$ & $\begin{array}{l}\text { Th } \\
(\mathrm{ppm})\end{array}$ & $\begin{array}{l}\mathrm{K} \\
(\%)\end{array}$ & $\begin{array}{l}\text { Dose rate } \\
\text { (Gy/ka) }\end{array}$ & $\begin{array}{l}\text { OD } \\
\text { of De } \\
(\%)\end{array}$ & $\begin{array}{l}\text { Average De } \\
\text { (Gy) }\end{array}$ & $\begin{array}{l}\text { CAM De } \\
\text { (Gy) }\end{array}$ & $\begin{array}{l}\text { MAM }{ }^{1} \text { De } \\
\text { (Gy) }\end{array}$ & $\begin{array}{l}\text { MAM }{ }^{2} \text { De } \\
\text { (Gy) }\end{array}$ & $\begin{array}{l}\text { Mean age } \\
\text { (ka) }\end{array}$ & $\begin{array}{l}\text { CAM age } \\
\text { (ka) }\end{array}$ & $\begin{array}{l}\text { MAM }{ }^{1} \\
\text { age } \\
\text { (ka) }\end{array}$ \\
\hline $2.25 \pm 0.32$ & $5.55 \pm 1.13$ & $2.01 \pm 0.10$ & $2.93 \pm 0.21$ & 27.30 & $10.95 \pm 0.93$ & $10.47 \pm 0.68$ & $6.86 \pm 0.42$ & $24.32 \pm 1.60$ & $3.7 \pm 0.4$ & $3.6 \pm 0.3$ & $2.3 \pm C$ \\
\hline
\end{tabular}

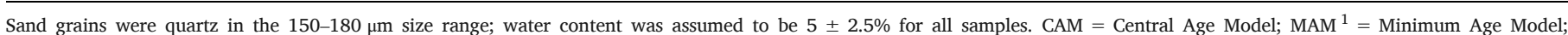
$\mathrm{MAM}^{2}=$ Maximum Age Model. 
Table 2

Location and characteristics of the MEM stations (all placed on clean rock salt surfaces). $\mathrm{V}=$ Vertical, $\mathrm{H}=$ Horizontal, $\mathrm{R}=$ Cave Roof, $\mathrm{F}=$ Cave Floor, St $=$ MEM Station.

\begin{tabular}{|c|c|c|c|c|c|c|}
\hline St & $\begin{array}{l}\text { Coordinates } \\
\text { (WGS 84) }\end{array}$ & $\begin{array}{l}\text { Altitude } \\
\text { (m asl) }\end{array}$ & Position & Description & $\begin{array}{l}\text { Days } \\
\text { elapsed }\end{array}$ & $\begin{array}{l}\text { Lowering } \\
(\mathrm{mm} / \mathrm{yr})\end{array}$ \\
\hline 1 & $\begin{array}{l}22^{\circ} 56^{\prime} 014^{\prime \prime} \\
S \\
68^{\circ} 18^{\prime} 468^{\prime \prime} \\
\mathrm{E}\end{array}$ & 2521 & V & $\begin{array}{l}500 \mathrm{~m} \text { East } \\
\text { of Valle de } \\
\text { la Luna } \\
\text { (VdL), under } \\
\text { an } \\
\text { abandoned } \\
\text { salt quarry, } \\
+/- \\
100 \mathrm{~m} \mathrm{~S} \text { of } \\
\text { the road. }\end{array}$ & 1457 & 0.40 \\
\hline 2 & $\begin{array}{l}22^{\circ} 56^{\prime} 014^{\prime \prime} \\
\mathrm{S} \\
68^{\circ} 18^{\prime} 468^{\prime \prime} \\
\mathrm{E}\end{array}$ & 2519 & $\mathrm{H}$ & $\begin{array}{l}\text { Same as } \\
\text { before, on } \\
\text { salt block on } \\
\text { the ground } \\
\text { at } 4 \mathrm{~m} \text { from } \\
\text { Station } 1 .\end{array}$ & 1457 & 0.92 \\
\hline 3 & $\begin{array}{l}22^{\circ} 55^{\prime} 446^{\prime \prime} \\
S \\
68^{\circ} 14^{\prime} 400^{\prime \prime} \\
E\end{array}$ & 2460 & $\mathrm{H}$ & $\begin{array}{l}\text { At the upper } \\
\text { entrance } \\
\text { (collapse } \\
\text { doline) of } \\
\text { Chulacao } \\
\text { cave, at } \\
50 \mathrm{~m} \\
\text { distance } \\
\text { from ancient } \\
\text { mine } \\
\text { reservoirs. }\end{array}$ & 1446 & 0.69 \\
\hline 4 & $\begin{array}{l}22^{\circ} 55^{\prime} 267^{\prime \prime} \\
\mathrm{S} \\
68^{\circ} 14^{\prime} 321^{\prime \prime} \\
\mathrm{E}\end{array}$ & 2502 & $\mathrm{~V}$ & $\begin{array}{l}400 \mathrm{~m} \\
\text { upstream of } \\
\text { Chulacao } \\
\text { main doline } \\
\text { entrance, on } \\
\text { the northern } \\
\text { bank of the } \\
\text { small valley. }\end{array}$ & 127 & 1.73 \\
\hline 5 & $\begin{array}{l}22^{\circ} 56^{\prime} 440^{\prime \prime} \\
\mathrm{S} \\
68^{\circ} 15^{\prime} 925^{\prime \prime} \\
\mathrm{E}\end{array}$ & 2437 & $\mathrm{H}$ & $\begin{array}{l}\text { On salt } \\
\text { block in the } \\
\text { bed of the } \\
\text { Quebrada } \\
\text { Lechuza, at } \\
\text { little more } \\
\text { than } 200 \\
\text { steps from } \\
\text { the cave } \\
\text { entrance. }\end{array}$ & 1451 & \\
\hline 6 & $\begin{array}{l}22^{\circ} 56^{\prime} 380^{\prime \prime} \\
S \\
68^{\circ} 15^{\prime} 961^{\prime \prime} \\
\mathrm{E}\end{array}$ & 2405 & $\mathrm{R}$ & $\begin{array}{l}\text { Cave roof in } \\
\text { upper } \\
\text { passage at } \\
20 \mathrm{~m} \text { from } \\
\text { the entrance } \\
\text { (flowstone) }\end{array}$ & 2917 & 0.03 \\
\hline 7 & $\begin{array}{l}22^{\circ} 56^{\prime} 380^{\prime \prime} \\
S \\
68^{\circ} 15^{\prime} 961^{\prime \prime} \\
\mathrm{E}\end{array}$ & 2405 & $\mathrm{~F}$ & $\begin{array}{l}\text { Floor of } \\
\text { upper } \\
\text { abandoned } \\
\text { meander, at } \\
3 \text { m height } \\
\text { (left side) } \\
\text { and at } 60 \mathrm{~m} \\
\text { from the } \\
\text { flowstone } \\
\text { entrance } \\
\text { climb. }\end{array}$ & 2918 & -0.03 \\
\hline
\end{tabular}

\section{$(4$}

the possible flood level, appear to be stable (with a lowering rate ranging from -0.03 and $+0.03 \mathrm{~mm} / \mathrm{yr}$ ) (Fig. 5C-D).

\subsection{Age of cave deposits and speleogenesis}

Bones and twigs or branches of wood collected inside the caves have been radiocarbon dated in order to develop a chronology for their deposition (Fig. 4, Table 3). Bones and twigs pre-date the floods that carried them into the caves. Although these samples might be much older than the caves and the floods, we believe they are penecon- dissolution rate measurements and historical rainfall records (De Waele et al., 2009c). In Chulacao Cave the stems of two different shrub species (Ephedra chilensis (Pingo Pingo) $\mathrm{CH} 3$ and Prosopis chilensis (Algarrobo) $\mathrm{CH} 4$, determination by Werner Schoch, Labor für Quartäre Hölzer), respectively 6 and $8 \mathrm{~cm}$ in diameter (around 30 rings), were found inside fluvial sediments cemented to the walls. The use of subfossil trees in salt caves is a powerful tool to reconstruct past landscapes, and cultural implications (Frumkin, 2009). Shrubs with stems of 6-8 cm diameter are not present in the watersheds of the investigated caves today, so they are evidence of a past wetter local climate in the catchment area.

In Cueva Lechuza de Campanario two diamictons have been dated to approximately 4.4 and $1.3 \mathrm{ka}$, respectively (De Waele et al., 2009a, $2009 \mathrm{~b}$; Table 3), indicating that the cave is at least 4.4 ka old, and most probably formed during the Holocene. The top of a 6-m thick sand-rich fan at the exit of the Palacio del Sal canyon, hundreds of meters downstream of the cave, provided an OSL CAM (Central Age Model) age of $3.6 \pm 0.3 \mathrm{ka}$, and minimum and maximum ages of $2.3 \pm 0.2 \mathrm{ka}$ and $8.3 \pm 0.8$ ka respectively, recording a period of localized channel activity in this area (Table 1). It is not excluded that this alluvial fan is related to the same flood registered in Cueva di Lechuza del Campanario (4.4 ka), but given the large errors in this OSL date other possibilities exist.

PS Palacio del Sal; CHF Chulacao Fossil Cave; CH Chulacao Cave; LCH Lechuza del Campanario Cave. All ages from De Waele et al., 2009a except for the four dates of samples "Lechuza".

Twigs and bones stuck in a cave ceiling or wall provide approximate (maximum) ages for important floods that carried these fragments into the cave, when such vegetal debris was available in the catchment area. The record of such floods shows that they appear to occur with more frequency in the periods 0-270 (CH1 and CH5), 470-920 (CHF1, CHF5, CH2, CH3 and CH4), 1300-1550 cal yr B.P. (CHF2, CHF3, CHF6, LCH2, LCH3, Lechuza-1, Lechuza-2, and Lechuza-7 samples) with two older samples centered at ca. 2073 and ca. 4419 cal yr B.P. (Table 3). One of these largest clusters (eight dates between 1200 and 1500 cal yr B.P.) corresponds to the local expansion of the Tiwanaku culture, when climate conditions and vegetation in the catchment areas of the salt caves were probably more favorable than today (Costa et al., 2004).

\section{Discussion}

\subsection{Holocene climate based on cave morphology and deposits}

The rapid evolution of the salt caves and their minimal age, obtained dating the debris flows they contain, helps reconstructing the environmental history of the area (see also Frumkin et al., 1991). Halite dissolution measurements using MEM stations, especially the one on the block in the external Lechuza river bed 200 steps downstream of the cave, give further insight into the velocity at which cave carving processes can take place. The investigated caves are through-caves that channel water underground from small catchments located at the western border of the Salar de Atacama. These valleys are believed to have formed during wet periods, such as the CAPE, which lasted until around 9.7 ka (Quade et al., 2008; Placzek et al., 2009; Saez et al., 2016) and older Pleistocene humid periods (Fig. 1). During these wetter periods the rivers of the area were probably capable of eroding and dissolving the rock salt entirely along their course, thus forming open canyons instead of caves. Some of the larger caves, with cave passages of 10-m height or even higher, however, might have formed during these wet CAPE periods. Assuming these canyons to have been carved by underground rivers flowing on salt, and knowing that one flood event, with a recurrence in the order of a decade (based on rainfall records of the area over the last century, Ortlieb, 1995 and Sesiano, 2006), leads to a dissolution of $2 \mathrm{~cm}$ or greater (MEM station of Quebrada Lechuza), a 10-m deep canyon might have formed in less than 5000 years. At this dissolution-erosion rate, smaller caves, such as Lechuza del Campanario, would have formed in a matter of less than 2000 years. The age of the oldest diamicton in this cave (ca. $4.4 \mathrm{ka}$ ), however, points to an older age. This debris flow 

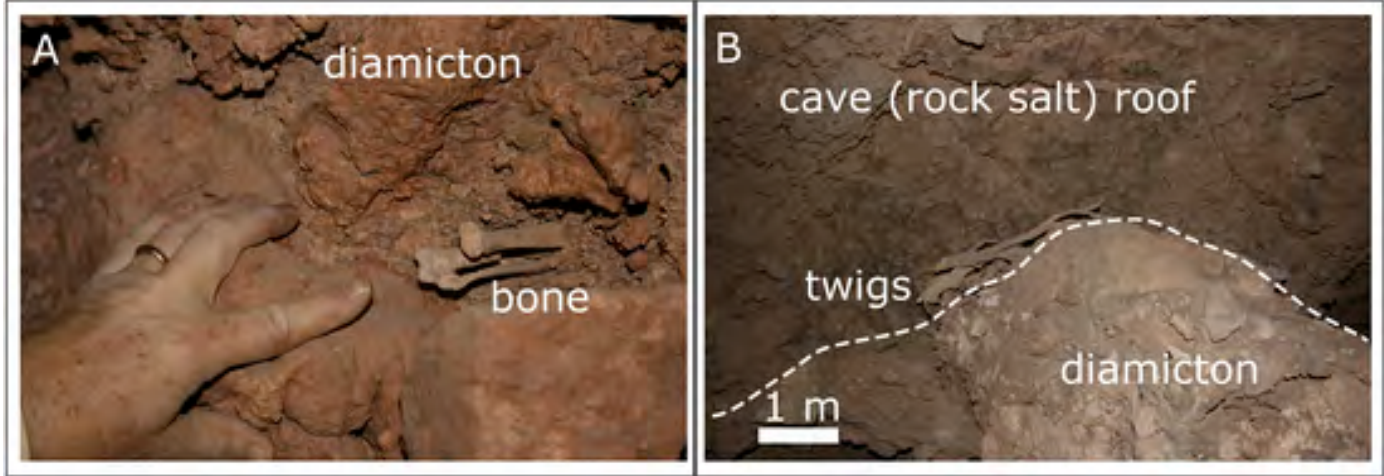

Fig. 4. Bones and twigs embedded in diamictons in Cueva Lechuza del Campanario.

Table 3

Cave wood and bone sample characteristics and radiocarbon ages.

\begin{tabular}{|c|c|c|c|c|c|c|}
\hline Sample ID & Type & $\begin{array}{l}\text { Lab } \\
\text { ID }\end{array}$ & $\begin{array}{l}\mathrm{pmC} \\
(1 \sigma)\end{array}$ & $\begin{array}{l}\delta^{13} \mathrm{C} \\
(\% o)\end{array}$ & Age ( $1 \sigma$ cal yr B.P.) & $\begin{array}{l}\text { Median probability } \\
\text { Age } \\
\text { (cal yr B.P.) }\end{array}$ \\
\hline $\mathrm{PS},+50-70 \mathrm{~cm}$ & Twigs & R 03265 & $118.27 \pm 0.34$ & -16.23 & Modern & Modern \\
\hline PS, Roof, $+3.5 \mathrm{~m}$ & Twigs & R 03266 & $76.65 \pm 0.22$ & -24.25 & $2010-2148$ & 2073 \\
\hline CHF 1 & Wood; branch & R 03267 & $90.09 \pm 0.26$ & -23.4 & $678-761$ & 715 \\
\hline CHF 2 & Wood; branch & R 03268 & $81.60 \pm 0.23$ & -22.88 & $1424-1560$ & 1500 \\
\hline CHF 3 & Wood; branch & R 03269 & $81.88 \pm 0.24$ & -24.27 & $1383-1531$ & 1464 \\
\hline CHF 4 & Wood; branch & R 03270 & $86.105 \pm 0.256$ & -25.56 & $968-1170$ & 1027 \\
\hline CHF 5 & Small bones & R 03271 & $89.769 \pm 0.245$ & -15.92 & 737-905 & 796 \\
\hline CHF 6 & Small bones & R 03272 & $82.712 \pm 0.229$ & -15.9 & $1376-1522$ & 1449 \\
\hline $\mathrm{CH} 1$ & Wood; branch & R 03273 & $98.165 \pm 0.283$ & -23.73 & 0-272 & 106 \\
\hline $\mathrm{CH} 2$ & Wood & R 03274 & $89.646 \pm 0.249$ & -12.32 & 794-918 & 856 \\
\hline $\mathrm{CH} 3$ & Wood stem & R 03275 & $94.286 \pm 0.284$ & -23.66 & $472-526$ & 504 \\
\hline $\mathrm{CH} 4$ & Wood stem & R 03276 & $91.652 \pm 0.27$ & -20.49 & $568-675$ & 653 \\
\hline CH 5 & Bone & R 03277 & $98.867 \pm 0.273$ & -18.56 & $0-262$ & 97 \\
\hline LCH 1 & Wood & R 03278 & $61.008 \pm 0.224$ & -21.78 & $4292-4519$ & 4419 \\
\hline LCH 2 & Twigs & R 03279 & $83.605 \pm 0.269$ & -21.84 & $1291-1360$ & 1319 \\
\hline LCH 3 & Bone & R 03280 & $83.754 \pm 0.24$ & -17.78 & $1301-1364$ & 1331 \\
\hline Lechuza-1 & Bone & 25559 & $83.77 \pm 25$ & -18.12 & 1195-1319 & 1294 \\
\hline Lechuza-2 & Bone & 255560 & $85.07 \pm 25$ & -18.18 & $1090-1270$ & 1205 \\
\hline Lechuza-7 & Bone & $255561 c$ & $84.79 \pm 25$ & -18.17 & $1117-1280$ & 1226 \\
\hline Lechuza-7 & Tooth & $255561 \mathrm{e}$ & $84.78 \pm 27$ & -11.53 & $1117-1280$ & 1226 \\
\hline
\end{tabular}

deposit and an alluvial fan at the downstream end of Palacio del Sal Cave, with an OSL CAM age of $3.6 \pm 0.3 \mathrm{ka}$ for the top sediments, appear to have been deposited during a widespread Middle Holocene wet phase, that is known in the region to have started around $5 \mathrm{ka}$ after a period of aridity (Saez et al., 2016). Such medium- to small sized caves must have formed earlier than the oldest dated debris flow, presumably towards the end of the dry phase following CAPE 2, at around $5 \mathrm{ka}$. During this period small rivers were probably active only rarely, with low flow rates, and were not capable of eroding and dissolving all the halite rock and preferred carving underground paths. This initial stage of cave formation must have occurred in a wet climate regime, when water was able to carve the caves but without entraining sediments. Debris flows, on the contrary, likely formed during high intensity events, the first of which was documented at ca. $4.4 \mathrm{ka}$. These sediment entrainment periods are more likely to occur during wetter conditions following a period of aridity, when weathered rock accumulated on hillslopes and valley sides. In addition, the alluvial fan at the downstream end of the Palacio del Sal Cave and visible near the road to Valle de la Luna, is 4-6 m thick and composed of reworked aeolian sand that presumably accumulated in the valley upstream of the cave prior to the mid-Holocene wet phase (last $5 \mathrm{ka}$ ) (Fig. 6). All these observations are compatible with a period of hyperaridity between the latest Pleistocene CAPE 2 and the Mid-
Holocene wet phases, as already recognized in the literature between around 10 and $7.5 \mathrm{ka}$, or for some authors up to $5 \mathrm{ka}$ (Quade et al., 2008; Saez et al., 2016), corresponding better to our data (first debris flow at $4.4 \mathrm{ka}$ ). The regolith colluviated at the base of slopes and the aeolian sand accumulated in the upper catchments could later be reworked as debris- and grain-flows within the caves and immediately outside them (at around $3.0 \mathrm{ka}$ ). A second diamicton in Lechuza del Campanario Cave was deposited ca. $1.3 \mathrm{ka}$ and might be a product of a later event of extreme precipitation following a more or less short period without rainfall capable of entraining sediments from the slopes and the valley floor.

Cave passage cross-sectional dimensions can be used as a proxy for the water flow that generated it (Frumkin et al., 1991; Frumkin, 1998). In all of the caves we studied, the cross-sections of the elliptical-shaped upper parts of the passages were large compared to the lower sections of the caves (Fig. 7), suggesting climatic control (these might have developed in more rainy conditions). This is similar to what happens in surface rivers where meander curvature increases with increasing width of the channel, implying also greater discharge (Williams, 1986). Underground rivers with larger flow rates thus appear to have carved the upper passages with larger meander curvature, suggesting higher precipitation during their formation. This is in apparent contrast with our speleogenetic model described earlier (with 


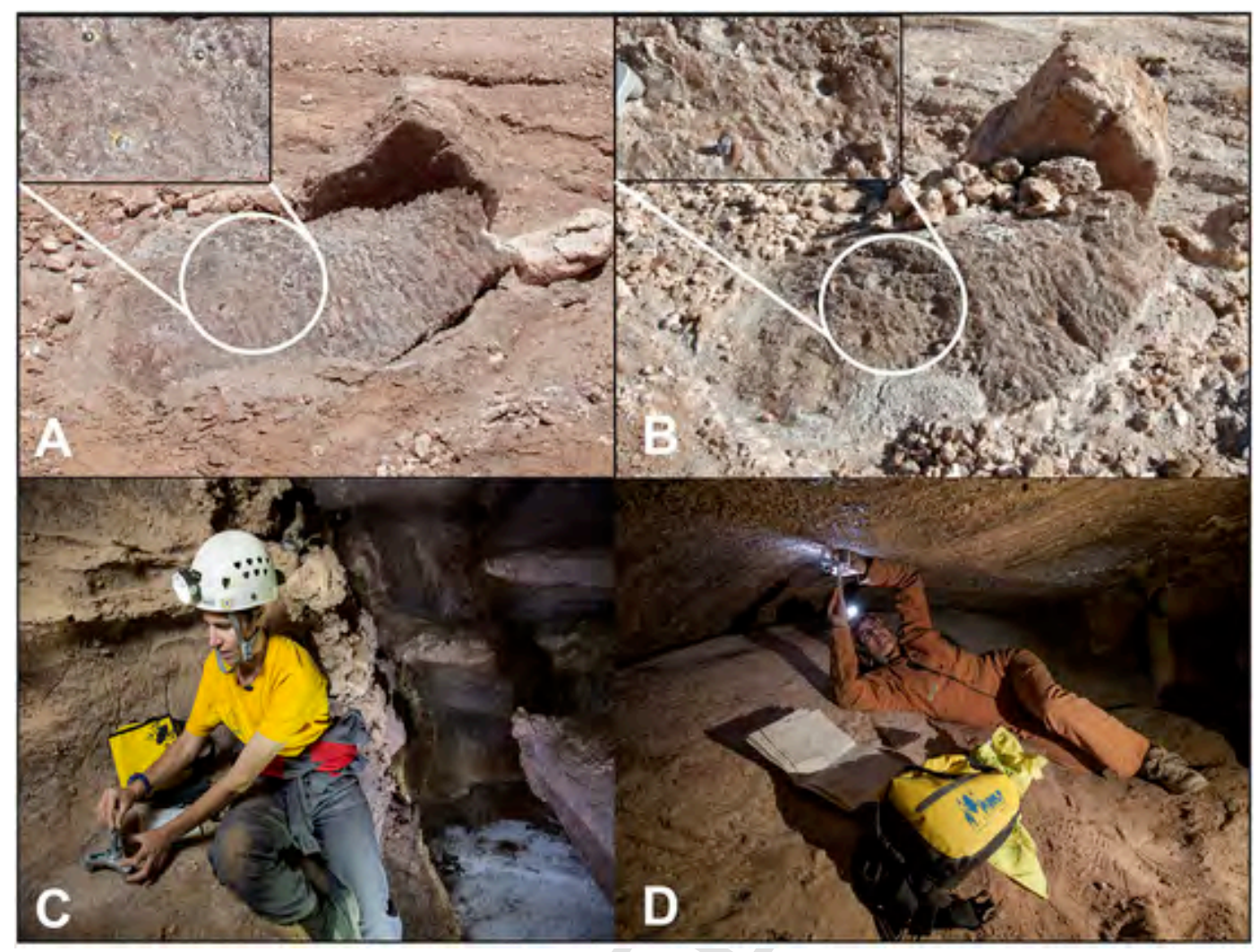

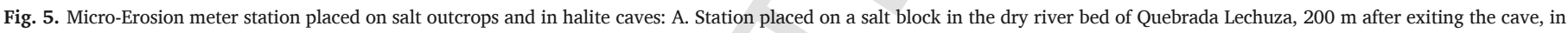

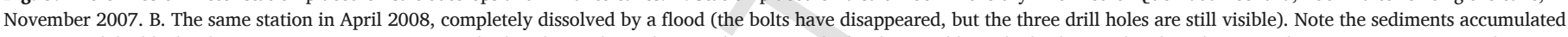

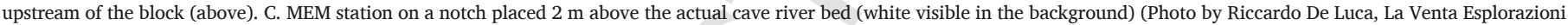
Geografiche). D. MEM station on the roof of a high notch, approximately $3 \mathrm{~m}$ above the present cave floor (Photo by Fulvio Iorio, La Venta Esplorazioni Geografiche).

caves forming during oscillating wet/dry climate period). This discrepancy can be explained by the magnitude of the rain events, and thus floods, that caused cave passage enlargement, and locally by paragenesis (Farrant and Smart, 2011). The earlier (and wider) cave passages would have formed during periods in which greater water flows occasionally crossed the caves, with a trend towards lower magnitude floods in more recent times. The presence of sediments in parts of these conduits might also indicate possible local paragenetic conditions during their formation. In this situation, sediment transport, deposition and dissolution are essentially coeval. Paragenetic processes appear to have been at least locally involved in the formation of the upper parts of the salt caves along the ceiling, as typical paragenetic forms such as flat roofs, pendants and ceiling channels demonstrate (Pasini, 1967; Renault, 1968; Pasini, 2009).

In the Lechuza del Campanario Cave, the original larger elliptical passage probably formed during the initial part of the mid-Holocene wet period (5-4.4 ka). Rain events during the initial period were never intense enough to be able to entrain large amounts of sediments accumulated at the bases of hillslopes. Slow sedimentation caused paragenesis to occur creating greater cross-sections. A greater amount of debris was mobilized during a particularly intense rain at ca. $4.4 \mathrm{ka}$, to form the older diamicton in the cave. According to Betancourt et al. (2000), the mid-Holocene wet period around the Salar de Atacama peaked at around 5 to $3 \mathrm{ka}$, which is consistent with the greater salt cave cross-section of the upper parts of the subterranean passages, and with the emplacement of the first diamicton in Lechuza del Campanario Cave by a particularly heavy rain event. Persistence of wet conditions, although weaker, resulted in the gradual erosion of the diamicton through entrenchment of the stream flowing through the cave. Smaller cross-sections point to an overall lower discharge in the carving rivers, and less important paragenetic (antigravitative) erosion.
After ca. 3 ka, a drier climate, punctuated by short wet intervals, allowed further accumulation of debris in the catchment of Lechuza del Campanario Cave. There is considerable evidence in the salt caves that the period ca. 1.0-1.5 ka (2 ages on bone, 4 on wood fragments, Table 3 ) was characterized by occasional heavy rainfall with one such event transporting the younger diamicton into Lechuza del Campanario Cave at ca. $1.3 \mathrm{ka}$. After ca. $1.3 \mathrm{ka}$ the mudflow deposit in the cave was entrenched under low intensity precipitation, with two minor episodes of heavier rainfall that are documented by the erosional characteristics (shape) of the cave cross section (Fig. 7). The fact that Cueva Lechuza del Campanario has a downstream entrance located $4 \mathrm{~m}$ lower than the cave trunk upstream is a clear sign that the cave river erosion is not able to keep pace with the uplift caused by the active fault over the last ca. 5 kyrs. In larger cave systems (with greater recharge areas) the floors are close-to-horizontal and covered with a blanket of alluvial and aeolian detritus, but the amount of water flowing occasionally through the caves is greater, and able to transport and reallocate these sediments. Downcutting in these caves keeps pace with the uplifting mountain, resulting in almost horizontal trunk passages, similar to what has been documented in Mount Sedom (Frumkin and Ford, 1995).

This scenario of halite cave genesis, and the speed at which this appears to have happened, is very similar to the findings in Mount Sedom (Israel) by Frumkin et al. (1991), where the oldest dated wooden debris is $7000 \mathrm{ka}$ old, and all caves appear to be of Holocene age. In some Iranian salt diapirs speleogenesis appears to have been active over the last ca. 50 kyrs, but all caves still accessible today have ages of less than 6 ka (Bruthans et al., 2010).

\subsection{Discussion of past precipitation and climate in the study area}

Alternating periods of sediment production and storage on hillslopes, and sediment evacuation through the channel, are typical of desert areas, 


\section{transverse profiles}
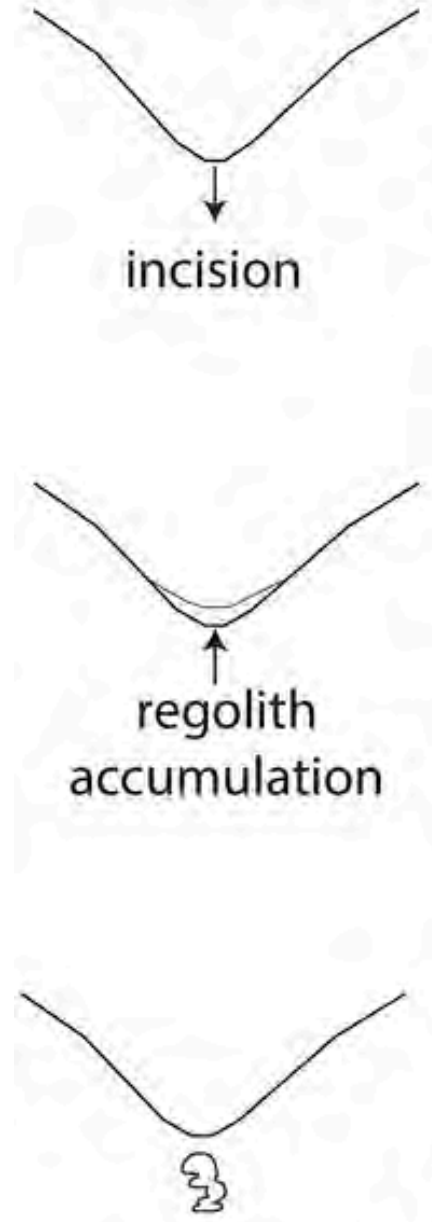

cave
formation

\section{longitudinal profiles}
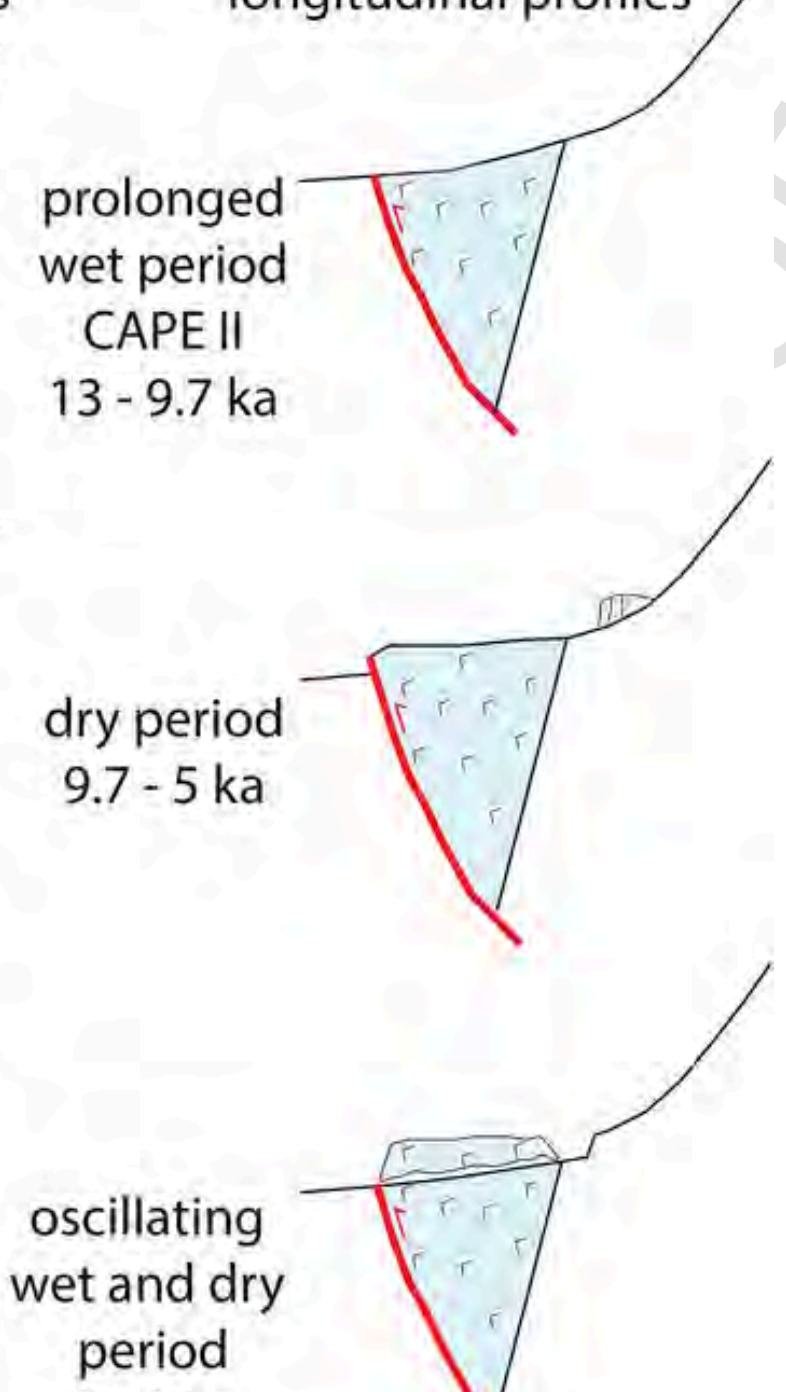

$5-0 \mathrm{ka}$

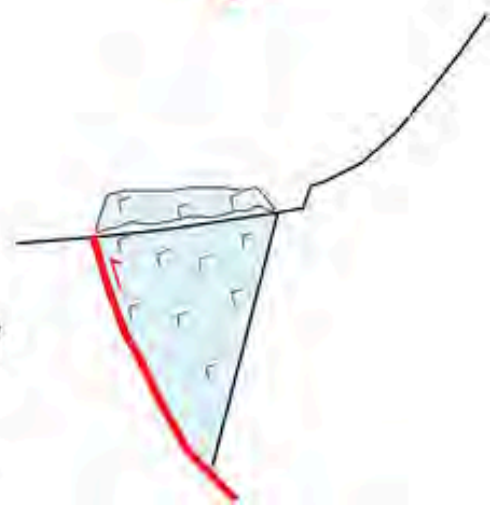

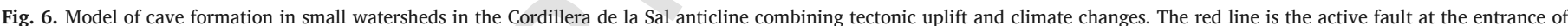

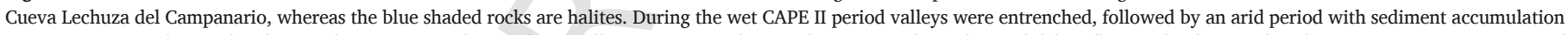

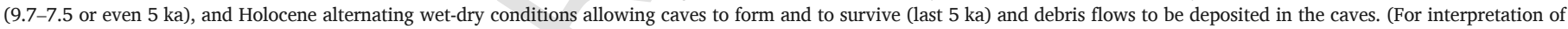
the references to color in this figure legend, the reader is referred to the web version of this article.)

documented by Clapp et al. (2000). Processes governing runoff nevertheless vary considerably across the region. Hillslope recharge-discharge patterns, surface water-groundwater interaction, and the emergence of riparian zones are examples of processes that vary across the basin (Martina and Entekhabi, 2006). This study has made it apparent that geomorphological processes in the Atacama Desert depend largely on precipitation amounts - both average annual values, but also extreme rains that generate floods and significant sediment transport.

The general (and obvious) perception that arid areas are characterized by relatively low average precipitation intensity, while rainfall intensities are relatively higher in wet areas, hides many possible differences between hydrology and geomorphology in 'arid' and 'humid' areas. This is illustrated in Fig. 8, which shows two precipitation intensity probability distributions with the same average, but different characteristics, particularly in the tails of the distributions where one has a higher probability density than the other. We tried to conceptualize a qualitative model to interpret the results obtained and the observed geomorphic features. This model does not take into account vegetation, since the density of plants, today and in the Holocene, was never enough to have a substantial role in sediment fixing on these salty arid slopes. Scattered vegetation debris (and bones), however, were entrained together with the sediments, allowing us to date these flood deposits.

To illustrate this model for deserts, we consider four different climatic regimes: two with a 'wet' climate and two with a 'dry' climate but with the two wet and two dry areas differing because in one there is a high probability of extreme rainfall events (high = long tail) and in the other a low probability of such events (low = short tail). These climate regimes affect geomorphologic processes significantly and therefore we use them in considering possible past climate changes in our study area.

We believe that the evolution of the salt caves in the Cordillera de la Sal can be explained in terms of four main climate regimes (Fig. 9), although a mixed scenario is probably the most realistic one. We conceptualize that during a lengthy arid period with a low frequency of intense rains cave development and valley incision by streams will be minimal and colluvial and/or aeolian sediment will accumulate on hillslopes and in the valleys (Fig. 9A). If the frequency of intense rains is higher, and colluvium can be entrained by runoff after rain, this might trigger mudflows that fill caves with diamictons, 


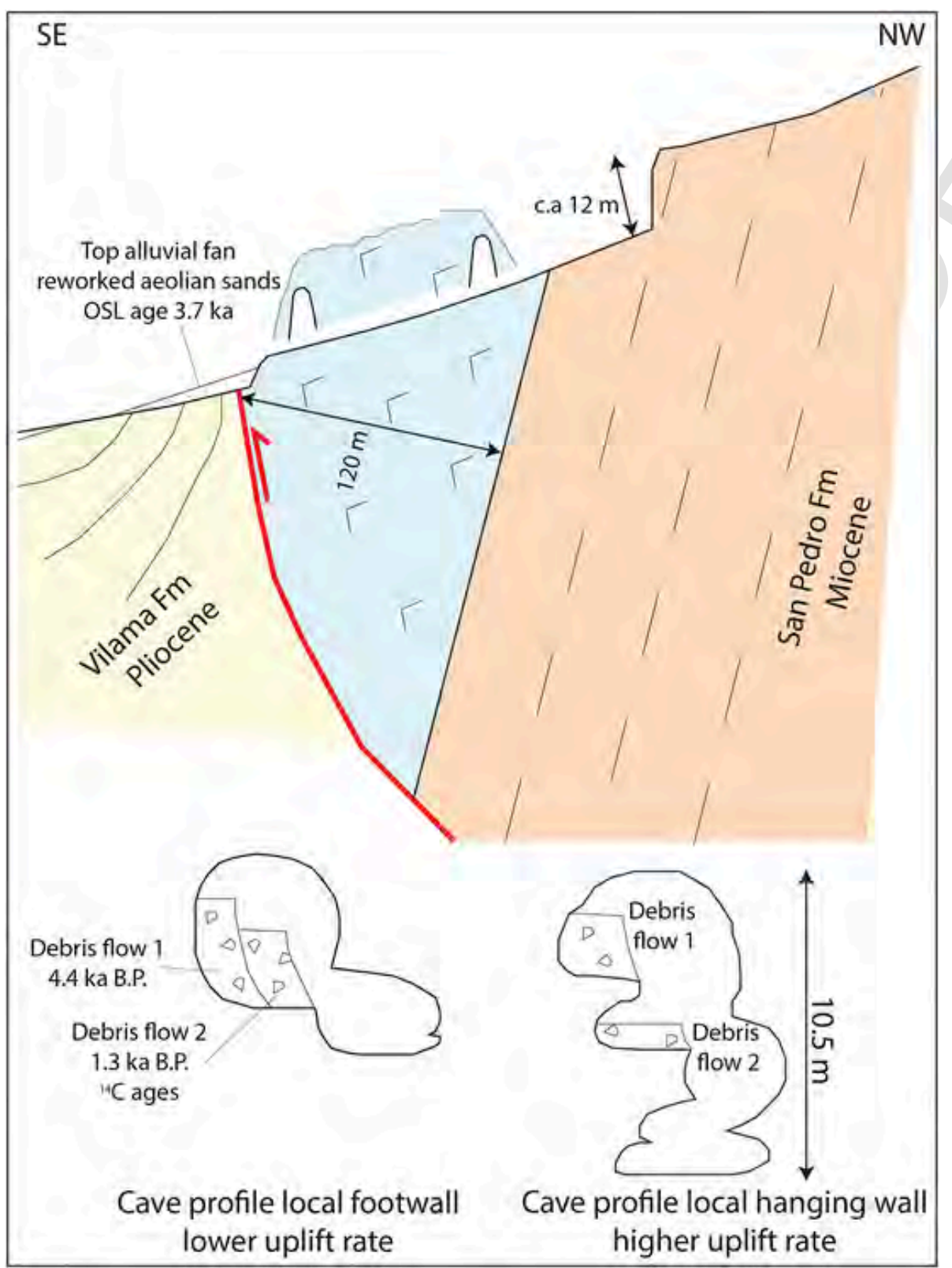

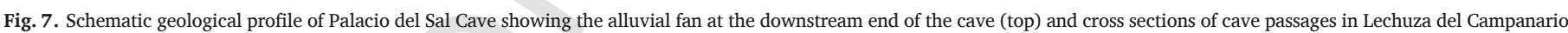

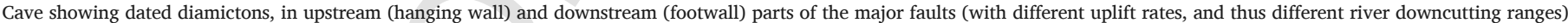
(bottom).

or in the case of aeolian sand deposits, fill caves with well-sorted sand, as occurred in Palacio del Sal Cave (Fig. 9B). However, if typical rains are of only modest intensity but long duration, there will be gradual removal of regolith from hillslopes and this will be transported through caves where cave entrenchment and passage enlargement will occur (Fig. 9C). Finally, for intense, long-duration precipitation events (Fig. 9D), there will be continuous removal of regolith from the hillslopes but with lower sediment concentrations in streams, resulting in cave passage enlargement and removal of previously deposited mudflow or aeolian deposits. The eventual fate of the caves if these wetter conditions were to persist for a long time may be the development of a surface stream channel that cuts into the caves and effectively destroys them. It is possible that some caves were destroyed in this way at the end of the Late Pleistocene.

\section{Conclusions}

The analysis of the cave deposits related to smaller catchments in the Cordillera de la Sal has allowed us to assess the impact of climate change landscape development in this part of the Salar de Atacama over the last thousands of years. We believe that some of the larger caves (e.g. Cueva Chulacao) might have started forming during the CAPE 2 wet period from ca. 12.7-9.7 ka, but that most medium- to small sized caves are mid-Holocene in age. In fact, no caves could form during the major arid period from ca. 9.7-5.0 ka, and our data show that most smaller caves (i.e. Lechuza del Campanario) formed at the onset of the wetter mid-Holocene period, in the time frame 5-4.4 ka, when precipitation was never intense enough to entrain sediments, but enough to trigger cave development (Fig. 9A). Our dissolution measurements confirm that cave formation may have happened in such short time spans. After this period, the mudflow into Lechuza del Campanario Cave at ca. 4.4 ka shows that annual rainfall and rainfall intensity increased during the mid-Holocene wet interval (Fig. 9B). A wet, low rainfall intensity period followed ca. 4.0-2.5 ka when the diamicton in Lechuza del Campanario Cave was entrenched and the alluvial fan at the downstream end of Palacio del Sal Cave was deposited ca. $3.6 \mathrm{ka}$. At ca. 2 ka there was a prolonged high-intensity rainfall event documented by the age of a twig 


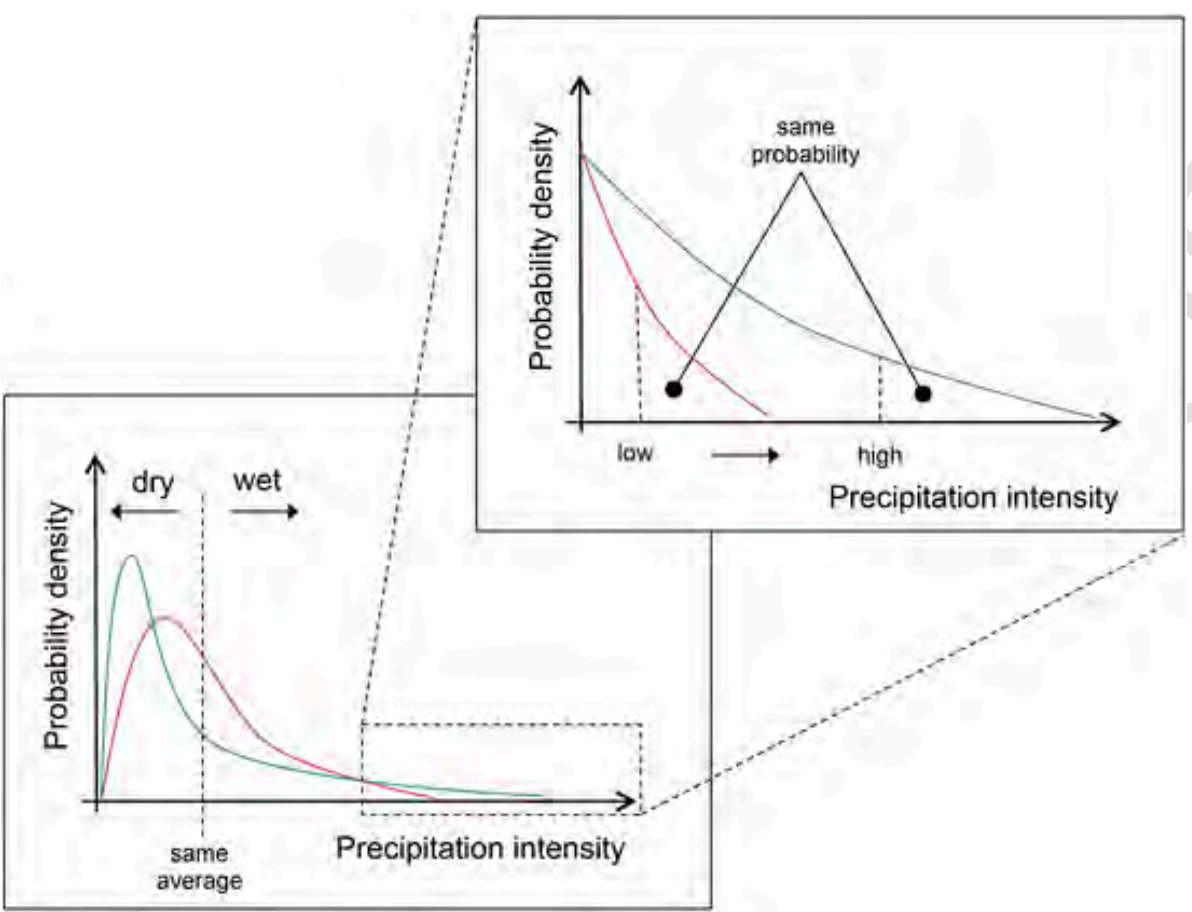

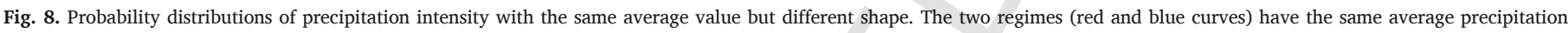

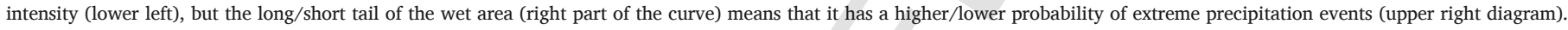
(For interpretation of the references to color in this figure legend, the reader is referred to the web version of this article.)

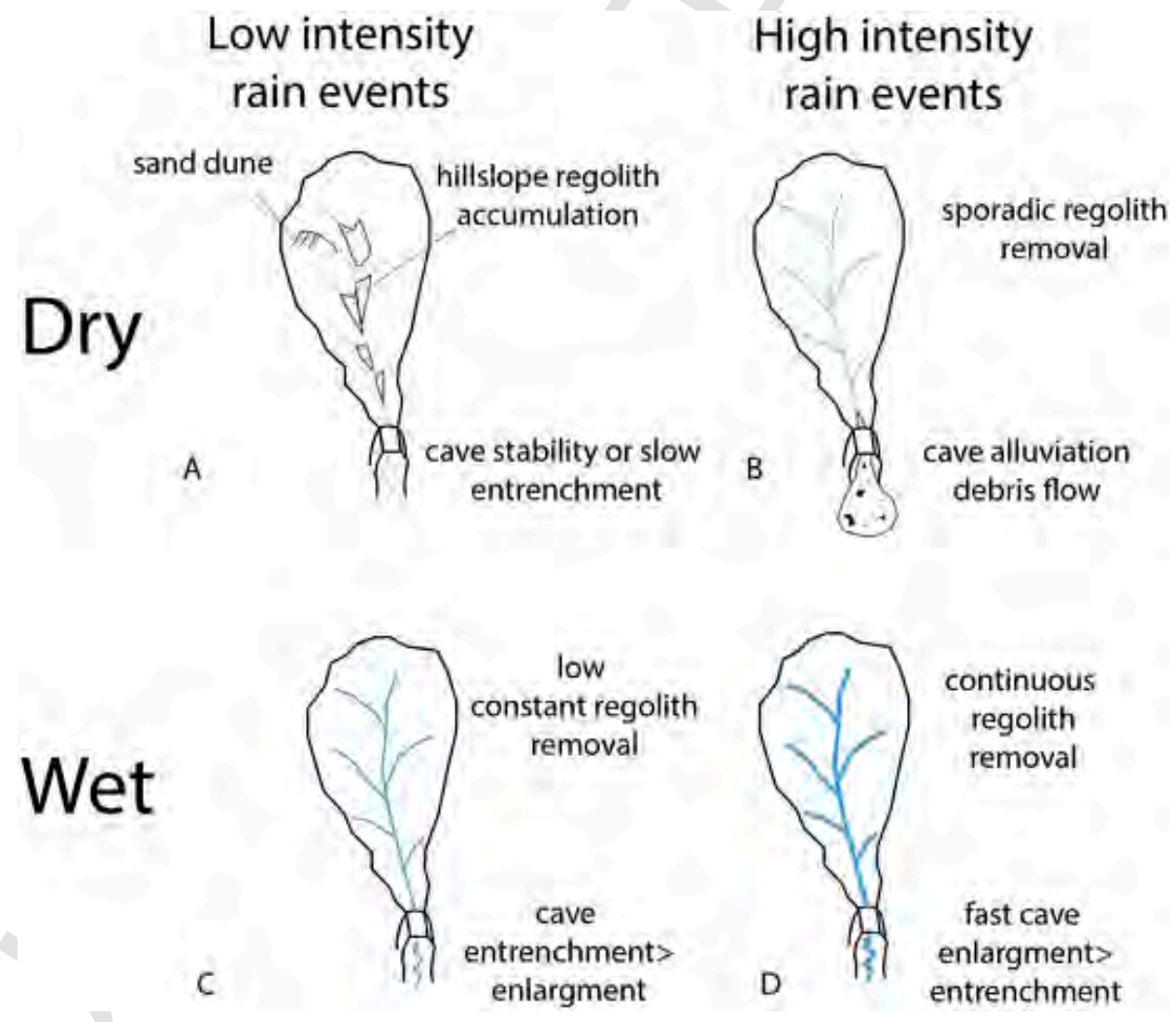

Fig. 9. Conceptual climatic model for the Central Atacama Desert based on stream and cave morphologies for the Late Pleistocene-Holocene.

stuck in the ceiling of the Palacio del Sal Cave (PS roof in Table 3). This event was followed by a dry/low rainfall intensity period until ca. $1.3 \mathrm{ka}$, when intense precipitation (dry/high intensity) produced a mudflow that deposited a second diamicton in Lechuza del Campanario Cave 2 (see Fig. 7). The cave evidence in the last ca. $1 \mathrm{ka}$ suggests a fluctuating climate. Cluster- ing of radiocarbon ages for wood and bone recovered from caves indicates increased rainfall intensity in the period ca. 1.25-1.55 ka, with a minor wet interval ca. $0.13 \mathrm{ka}$. This wetter time interval, corresponding to the Medieval Climate Anomaly, has been an archaeologically important period in the Atacama Desert (Tiwanaku culture). 


\section{Uncited references}

Baker et al., 2005

Gayo et al., 2012

Nester et al., 2007

Rech et al., 2002

Rigsby et al., 2005

Sylvestre et al., 1999

\section{Declaration of competing interest}

The authors declare that they have no known competing financial interests or personal relationships that could have appeared to influence the work reported in this paper.

\section{Acknowledgments}

This research was made possible thanks to the Integrated Project "Atacama" of the former "Dipartimento di Scienze della Terra e Geologico-Ambientali" of Bologna University co-funded by the "Fondazione della Cassa di Risparmio di Bologna”. Comments by Claudio Latorre on a previous version of this paper were most useful. We sincerely thank reviewers Augusto Auler and Amos Frumkin for their additional useful comments and corrections on this version. Thanks to Kevin Downey, Elio Padovan and Galliano Bressan for useful discussions on caves of the area. Luca Zini and Franco Cucchi helped during fieldwork. The 2015 expedition was organized by Commissione Grotte "Eugenio Boegan" Trieste and La Venta Esplorazioni Geografiche Treviso, whereas the 2018 expedition was entirely guided by La Venta Esplorazioni Geografiche Treviso and benefited from a National Geographic Exploration Grant (\#CP-089R-17, JDW). Fig. 2 was made with the help of Alessio Ponza.

\section{References}

Aitken, M J, 1985. Thermoluminescence Dating. Academic Press 359 p.

Aitken, M J, 1998. An Introduction to Optical Dating. Oxford University Press, Oxford.

Baker, P A, Fritz, S C, Garland, J, Ekdahl, E, 2005. Holocene hydrologic variation at Lake Titicaca, Bolivia/Peru, and its relationship to North Atlantic climate variation. J. Quat. Sci. 20 (7-8), 655-662.

Betancourt, J L, Latorre, C, Rech, J A, Quade, J, Rylander, K A, 2000. A 22,000-year record of monsoonal precipitation from northern Chile's Atacama Desert. Science 289, 1542-1546. doi:10.1126/science.289.5484.1542.

Bobst, A L, Lowenstein, T K, Jordan, T E, Godfrey, L V, Ku, T L, Luo, S D, 2001. A 106 ka paleoclimate record from drill core of the Salar de Atacama, northern Chile. Palaeogeogr. Palaeoclimatol. Palaeoecol. 173 (1-2), 21-42. doi:10.1016/ S0031-0182(01)00308-X.

Bosák, P, Bruthans, J, Filippi, M, Svoboda, T, Šmiíd, J, 1999. Karst and caves in salt diapirs, SE Zagros Mts. (Iran). Acta Carsologica 28 (2), 41-75.

Bøtter-Jensen, L, Duller, G A T, Murray, A S, Banerjee, D, 1999. Blue light emitting diodes for optical stimulation of quartz in retrospective dosimetry and dating. Radiat. Prot. Dosim. 84, 335-340.

Bruthans, J, Filippi, M, Zare, M, Churáčková, Z, Asadi, N, Fuchs, M, Adamovič, J, 2010. Evolution of salt diapir and karst morphology during the last glacial cycle: effects of sea-level oscillation, diapir and regional uplift, and erosion (Persian Gulf, Iran). Geomorphology 121 (3-4), 291-304.

Clapp, E M, Bierman, P R, Schick, A P, Lekach, J, Enzel, Y, Caffee, M, 2000. Sediment yield exceeds sediment production in arid region drainage basins. Geology 28 (11), 995-998. doi:10.1130/0091-7613.

Costa, M A, Alves Neves, W, Hubbe, M, 2004. Influencia de ku en la calidad de vida biológica de la población prehistórica de San Pedro de Atacama. Estudios atacameños 27, 103-116.

Cunningham, A C, Wallinga, J, 2010. Selection of integration time intervals for quartz OSL decay curves. Quat. Geochronol. 5, 657-666.

De Waele, J, Forti, P, 2010. Salt rims and blisters: peculiar and ephemeral formations in the Atacama Desert (Chile). Z. Geomorphol. 54, 51-67. doi:10.1127/0372-8854/ 2010/0054S2-0004.

De Waele, J, Padovan, E, 2016. The salt from within. NSS News 74 (8), 4-9.

De Waele, J, Forti, P, Picotti, V, Galli, E, Rossi, A, Brook, G A, Zini, L, Cucchi, F, 2009. Cave deposits in Cordillera de la Sal (Atacama, Chile). GeoActa special publication 2, 97-111 Bologna.

De Waele, J, Picotti, V, Forti, P, Brook, G, Cucchi, F, Zini, L, 2009. Age of caves in the Cordillera de la Sal (Atacama, Chili). In: White, W B (Ed.), 15th International Congress on Speleology. Kerrville, Texas, USA, pp. 825-830.

De Waele, J, Picotti, V, Zini, L, Cucchi, F, Forti, P, 2009. Karst phenomena in the Cordillera de la Sal (Atacama, Chile). GeoActa special publication 2, 113-127 Bologna.

De Waele, J, Carbone, C, Sanna, L, Vattano, M, Galli, E, Sauro, F, Forti, P, 2017. Secondary minerals from salt caves in the Atacama Desert (Chile): a hyperarid and hypersaline environment with potential analogies to the Martian subsurface. Int. J. Speleol. 46 (1), 51-66.
De Waele, J, Pisani, L, Pastore, C, Vattano, M, 2019. Leggere le grotte nel sale di Atacama (Cile). Speleologia 81, 44-51.

Deike, G H, White, W B, 1969. Sinuosity in limestone solution conduits. Am. J. Sci. 267, $230-241$.

Duller, G A T, 1999. Luminescence Analyst Computer Programme V2.18. Department of Geography and Environmental Sciences, University of Wales, Aberystwyth.

Dunai, T J, Lopez, G A G, Juez-Larre, J, 2005. Oligocene-Miocene age of aridity in the Atacama Desert revealed by exposure dating of erosion-sensitive landforms. Geology 33 (4), 321-324. doi:10.1130/G21184.1.

Evenstar, L A, Hartley, A J, Archer, S G, Neilson, J E, 2015. Climatic and halokinetic controls on alluvial-lacustrine sedimentation during compressional deformation, Andean forearc, northern Chile. Basin Res. 28 (5), 634-657. doi:10.1111/bre.12124.

Farrant, A R, Smart, P L, 2011. Role of sediment in speleogenesis; sedimentation and paragenesis. Geomorphology 134 (1-2), 79-93.

Frumkin, A, 1998. Salt cave cross-sections and their paleoenvironmental implications. Geomorphology 23, 183-191.

Frumkin, A, 2009. Stable isotopes of a subfossil Tamarix tree from the Dead Sea region, Israel, and their implications for the Intermediate Bronze Age environmental crisis. Quat. Res. 71, 319-328.

Frumkin, A, Ford, D C, 1995. Rapid entrenchment of stream profiles in the salt caves of Mount Sedom, Israel. Earth Surf. Process. Landf. 20, 139-152.

Frumkin, A, Magaritz, M, Carmi, I, Zak, I, 1991. The Holocene climatic record of the salt caves of Mount Sedom, Israel. The Holocene 1 (3), 191-200.

Fryer, S, 2005. Halite caves of the Atacama. National Speleological Society News 63 (11), 4-19.

Galbraith, R F, Roberts, R G, 2012. Statistical aspects of equivalent dose and error calculation and display in OSL dating: an overview and some recommendations. Quaternary Geochronology 11, 1-27.

Galbraith, R F, Roberts, R G, Laslett, G M, Yoshida, H, Olley, J M, 1999. Optical dating of single and multiple grains of quartz from Jinmium rock shelter, Northern Australia: part I, experimental design and statistical models. Archaeometry 41, 338-364.

Garreaud, R D, Aceituno, P, 2001. Interannual rainfall variability over the South American $\begin{array}{lllll}\text { Altiplano. J. Clim. } 14 & \text { (12), 2779-2789. doi:10.1175/ }\end{array}$ 1520-0442(2001)014<2779:IRVOTS > 2.0.CO;2.

Garreaud, R D, Vuille, M, Clement, A C, 2003. The climate of the Altiplano: observed current conditions and mechanisms of past changes. Palaeogeogr. Palaeoclimatol. Palaeoecol. 194 (1-3), 5-22. doi:10.1016/S0031-0182(03)00269-4.

Garreaud, R D, Vuille, M, Compagnucci, R, Marengo, J, 2009. Present-day south american climate. Palaeogeogr. Palaeoclimatol. Palaeoecol. 281 (3), 180-195.

Garreaud, R D, Molina, A, Farias, M, 2010. Andean uplift, ocean cooling and Atacama hyperaridity: a climate modeling perspective. Earth Planet. Sci. Lett. 292 (1-2), 39-50. doi:10.1016/j.epsl.2010.01.017.

Gayo, E M, Latorre, C, Jordan, T E, Nester, P L, Estay, S E, Ojeda, K F, Santoro, C M, 2012. Late Quaternary hydrological and ecological changes in the hyperarid core of the northern Atacama Desert ( $21^{\circ}$ S). Earth Sci. Rev. 113, 120-140. doi:10.1016/ j.earscirev.2012.04.003.

Godfrey, L V, Jordan, T E, Lowenstein, T K, Alonso, R L, 2003. Stable isotope constraints on the transport of water to the Andes between $22^{\circ}$ and $26^{\circ} \mathrm{S}$ during the last glacial cycle. Paleogeogr. Paleoclimatol. Paleoecol. 194, 299-317. doi:10.1016/ S0031-0182(03)00283-9.

Grosjean, M, van Leeuwen, J F N, van der Knaap, W O, Geyh, M A, Ammann, B, Tanner, W, Messerli, B, Nunez, L A, Valero-Garces, B L, Veit, H, 2001. A 22,000 C-14 year BP sediment and pollen record of climate change from Laguna Miscanti (23 degrees S), northern Chile. Glob. Planet. Chang. 28 (1-4), 35-51. doi:10.1016/ S0921-8181(00)00063-1.

Grosjean, M, Cartajena, I, Geyh, M A, Nunez, L, 2003. From proxy data to paleoclimate interpretation: the mid-Holocene paradox of the Atacama Desert, northern Chile. Palaeogeogr. Palaeoclimatol. Palaeoecol. 194 (1-3), 247-258. doi:10.1016/ S0031-0182(03)00280-3.

Grosjean, M, Santoro, C M, Thompson, L G, Nunez, L, Standen, V G, 2007. Mid-Holocene climate and culture change in the South Sentral Andes. In: Anderson, D G, Maasch, K A, Sandweiss, D H (Eds.), Climate Change an Cultural Dynamics: A Global Perspective on Mid-Holocene Transitions. Elsevier, Amsterdam, pp. 51-115.

Hartley, A J, Chong, G, 2002. Late Pliocene age for the Atacama Desert: implications for the desertification of western South America. Geology 30 (1), 43-46.

High, C, Hanna, F K, 1970. Method for the direct measurements of erosion on rock surfaces: British Geomorphological Research Group. Technical Bulletin 5, 1-25.

Hogg, A G, Hua, Q, Blackwell, P G, Buck, C E, Guildersno, T P, Heaton, T J, Niu, M, Palmer, J G, Reimer, P J, Reimer, R W, Turney, C S M, Zimmerman, S, 2013. SHCal13 southern hemisphere calibration, 0-50,000 years cal BP. Radiocarbon 55 (4), 1889-1903.

Horton, B K, 2018. Sedimentary record of Andean mountain building. Earth Sci. Rev. 178, 279-309.

Houston, J, 2006. Variability of precipitation in the Atacama desert: its causes and hydrological impact. Int. J. Climatol. 26, 2181-2198. doi:10.1002/joc.1359.

Houston, J, Hartley, A J, 2003. The central Andean west-slope rainshadow and its potential contribution to the origin of hyper-aridity in the Atacama Desert. Int. J. Climatol. 23, 1453-1464. doi:10.1002/joc.938.

Jordan, T E, Mpodozis, C, Muñoz, N, Blanco, N, Pananont, P, Gardeweg, M, 2007. Cenozoic subsurface stratigraphy and structure of the Salar de Atacama Basin, northern Chile. J. S. Am. Earth Sci. 23 (2-3), 122-146. doi:10.1016/ j.jsames.2006.09.024.

Jungers, M C, Heimsath, A M, Amundson, R, Balco, G, Shuster, D, Chong, G, 2013. Active erosion-deposition cycles in the hyperarid Atacama Desert of Northern Chile. Earth Planet. Sci. Lett. 371-372, 125-133. doi:10.1016/j.epsl.2013.04.005.

Latorre, C, Betancourt, J L, Rylander, K A, Quade, J, 2002. Vegetation invasions into absolute desert: a 45000 yr rodent midden record from the Calama-Salar de Atacama basins, northern Chile (lat 22 degrees-24 degrees S). Geol. Soc. Am. Bull. 114 (3), 349-366.

Latorre, C, Betancourt, J L, Rylander, K A, Quade, J, Matthei, O, 2003. A vegetation history from the arid prepuna of northern Chile (22-23 degrees $S$ ) over the last 13,500 years. 
Palaeogeogr. Palaeoclimatol. Palaeoecol. 194 (1-3), 223-246. doi:10.1016/ S0031-0182(03)00279-7.

Latorre, C, Betancourt, J L, Arroyo, M T K, 2006. Late Quaternary vegetation and climate history of a perennial river canyon in the Rio Salado basin (22 degrees $S$ ) of Northern Chile. Quat. Res. 65 (3), 450-466. doi:10.1016/j.yqres.2006.02.002.

Latorre, C, Santoro, C M, Ugalde, P C, Gayo, E M, Osorio, D, Salas-Egaña, C, De Pol-Holz, R, Joly, D, Rech, J A, 2013. Late Pleistocene human occupation of the hyperarid core in the Atacama Desert, northern Chile. Quat. Sci. Rev. 77, 19-30. doi:10.1016/ j.quascirev.2013.06.008.

Magilligan, F J, Goldstein, P S, Fisher, G B, Bostick, B C, Manners, R B, 2008. Late Quaternary hydroclimatology of a hyper-arid Andean watershed: climate change, floods, and hydrologic responses to the El Nino-Southern Oscillation in the Atacama Desert. Geomorphology 101 (1-2), 14-32. doi:10.1016/j.geomorph.2008.05.025.

Markey, B G, Bøtter-Jensen, L, Duller, G A T, 1997. A new flexible system for measuring thermally and optically stimulated luminescence. Radiat. Meas. 27, 83-90.

Martina, M L V, Entekhabi, D, 2006. Identification of runoff generation spatial distribution using conventional hydrologic gauge time series. Water Resour. Res. 42 (8)

Morales, M S, Christie, D A, Villalba, R, Argollo, J, Pacajes, J, Silva, J S, Alvarez, C A, Llancabure, J C, Soliz Gamboa, C C, 2012. Precipitation changes in the South American Altiplano since 1300AD reconstructed by tree-rings. Clim. Past 8, 653-666. doi:10.5194/cp-8-653-2012.

Muñoz, N, Charrier, R, Jordan, T, 2002. Interactions between basement and cover during the evolution of the Salar de Atacama Basin, northern Chile. Rev. Geol. Chile 29 (1), 55-80. doi:10.4067/S0716-02082002000100004.

Murray, A S, Wintle, A G, 2000. Luminescence dating of quartz using an improved single-aliquot regenerative-dose protocol. Radiat. Meas. 32 (1), 57-73.

Nester, P L, Gayò, E, Latorre, C, Jordan, T E, Blanco, N, 2007. Perennial stream discharge in the hyperarid Atacama Desert of northern Chile during the latest Pleistocene. Proc. Natl. Acad. Sci. 104 (50), 19724-19729. doi:10.1073/pnas.0705373104.

Ortlieb, L, 1994. Major historical rainfalls in Central Chile and the chronology of Enso events during the 16th-19th-centuries. Rev. Chil. Hist. Nat. 67 (4), 463-485.

Ortlieb, L, 1995. Eventos El Niño y episodios lluviosos en el desierto de Atacama: el registro de los últimos dos siglos. Bull. Inst. fr. études andines 24 (3), 519-537.

Padovan, E, 2015. L'esplorazione delle grotte nella Cordillera de la Sal Salar de Atacama Chile. In: De Nitto, L, Maurano, F, Parise, M (Eds.), Atti del XXII Congresso Nazionale di Speleologia - Euro Speleo Forum 2015 "Condividere i dati”. In: Pertosa-Auletta (SA) 30 maggio-2 giugno 2015, Memorie dell'Istituto Italiano di Speleologia, Serie II(29). pp. 617-628.

Pasini, G, 1967. Nota preliminare sul ruolo speleogenetico dell'erosione "antigravitativa". Le Grotte d'Italia 4 (1), 75-90.

Pasini, G, 2009. A terminological matter: paragenesis, antigravitative erosion or antigravitational erosion? Int. J. Speleol. 38 (2), 129-138.

Placzek, C J, Quade, J, Betancourt, J L, Patchett, P J, Rech, J A, Latorre, C, Matmon, A, Holmgren, C, English, N B, 2009. Climate in the dry Central Andes over geologic, millennial, and interannual timescales. Ann. Mo. Bot. Gard. 96, 386-397.

Placzek, C J, Matmon, A, Granger, D E, Quade, J, Niedermann, S, 2010. Evidence for active landscape evolution in the hyperarid Atacama from multiple terrestrial cosmogenic nuclides. Earth Planet. Sci. Lett. 295 (1-2), 12-20. doi:10.1016/j.epsl.2010.03.006.

Prescott, J R, Hutton, J T, 1994. Cosmic ray contributions to dose rates for luminescence and ESR dating: large depths and long-term time variations. Radiat. Meas. 23, 497-500.

Quade, J, Rech, J A, Betancourt, J L, Latorre, C, Quade, B, Rylander, K A, Fisher, T, 2008. Paleowetlands and regional climate change in the central Atacama Desert, northern Chile. Quat. Res. 69 (3), 343-360. doi:10.1016/j.yqres.2008.01.003.

Rech, J A, Quade, J, Betancourt, J L, 2002. Late Quaternary paleohydrology of the central Atacama Desert (lat 22 degrees-24 degrees S), Chile. Geol. Soc. Am. Bull. 114 (3), 334-348. doi:10.1130/0016-7606(2002)114<0334:LQPOTC > 2.0.CO;2.

Rech, J A, Currie, B S, Michalski, G, Cowan, A M, 2006. Neogene climate change and uplift in the Atacama Desert, Chile. Geology 34 (9), 761-764. doi:10.1130/G22444.1.

Rech, J A, Currie, B S, Shullenberger, E D, Dunagan, S P, Jordan, T E, Blanco, N, Tomlinson, A J, Rowe, H D, Houston, J, 2010. Evidence for the development of the Andean rain shadow from a Neogene isotopic record in the Atacama Desert, Chile. Earth Planet. Sci. Lett. 292 (3-4), 371-382.

Renault, Ph, 1968. Contribution à l' étude des actions mécaniques et sédimentologiques dans la spéléogenèse. 3e partie: Les facteurs sédimentologiques. Annales de Spéléologie 23 (3), 529-596.

Rigsby, C A, Bradbury, J P, Baker, P A, Rollins, S M, Warren, M R, 2005. Late Quaternary palaeolakes, rivers, and wetlands on the Bolivian Altiplano and their palaeoclimatic implications. J. Quat. Sci. 20 (7-8), 671-691.

Rubilar, J, Martínez, F, Arriagada, C, Becerra, J, Bascuñán, S, 2017. Structure of the Cordillera de la Sal: a key tectonic element for the Oligocene-Neogene evolution of the Salar de Atacama basin, Central Andes, northern Chile. J. S. Am. Earth Sci. 2017. doi:10.1016/j.jsames.2017.11.013.

Saez, A, Godfrey, L V, Herrera, C, Chong, G, Pueyo, J J, 2016. Timing of wet episodes in Atacama Desert over the last $15 \mathrm{ka}$. The Groundwater Discharge Deposits (GWD) from Domeyko Range at $25^{\circ} \mathrm{S}$. Quat. Sci. Rev. 145, 82-93. doi:10.1016/ j.quascirev.2016.05.036.

Salomon, J-N, 1995. Le Chili. Pays des karsts extrèmes. Karstologia 24, 52-56.

Sesiano, J, 2006. Evolution actuelle des phénomènes karstiques dans la Cordillera de la Sal (Atacama, Nord Chili). Karstologia 47, 49-54.

Sesiano, J, 2009. Nouvelles observations sur un massif de sel gemme dans la Cordillera de la Sal, désert d'Atacama, nord du Chili. Archives des Sciences Génève 62, 71-86.

Stuiver, M, Reimer, P J, 1993. Extended C-14 data-base and revised Calib 3.0 C-14 age calibration program. Radiocarbon 35 (1), 215-230.

Sylvestre, F, Servant, M, Servant-Vildary, S, Causse, C, Fournier, M, Ybert, J P, 1999. Lake-level chronology on the Southern Bolivian Altiplano (18-23 S) during late-glacial time and the early Holocene. Quat. Res. 51 (1), 54-66.

Trudgill, S, High, C, Hanna, K, 1981. Improvements to the micro-erosion meter (MEM): British Geomorphological Research Group. Technical Bulletin 29, 3-17.
Van Gundy, J J, White, W B, 2009. Sediment flushing in Mystic Cave, West Virginia, USA, in response to the 1985 Potomac Valley flood. Int. J. Speleol. 38 (2), 103-109. doi:10.5038/1827-806X.38.2.2.

Vogel, J S, Southon, J R, Nelson, D E, Brown, T A, 1984. Performance of catalytically condensed carbon for use in accelerator mass spectrometry. Nuclear Instruments and Methods in Physics Research B5, 289-293. doi:10.1016/0168-583X(84)90529-9.

Williams, G P, 1986. River meanders and channel size. J. Hydrol. 88, 147-164. 